\title{
Selling Land and Religion
}

\author{
Eang L. Ngov ${ }^{*}$
}

\section{INTRODUCTION}

Over the course of decades, thousands of religious monuments have been donated to towns and cities. Local, state, and federal governments now, as a result of Pleasant Grove City v. Summum, ${ }^{1}$ have greater freedom to accept or reject religious monuments, symbols, and objects ${ }^{2}$ donated to them for display in public spaces without violating the Free Speech Clause of the Constitution. ${ }^{3}$ In Pleasant Grove City, the city displayed a donated monument of the Ten Commandments in its public park but rejected a monument of the Seven Aphorisms donated by Summum, a religious organization. ${ }^{4}$ The Supreme Court characterized displays of monuments in public spaces as government speech, which

* Associate Professor, Barry University Dwayne O. Andreas School of Law. B.A., magna cum laude, Phi Beta Kappa, University of Florida; J.D., University of California at Berkeley School of Law.

For Jade. I thank Leslie Griffin, Frederick Jonassen, John Kang, Heather Kolinsky, Judith Koons, Bruce Ledewitz, Daniel P. O’Gorman, and Enrique Guerra Pujol for their insightful comments and conversations. I am grateful for the excellent research assistance of Rania Arwani, Christopher A. Bailey, John Berry, Bernice Bird, Jenna Goodwin, Laura Johnson, Lance Leider, Jacqueline Smith, Vanessa Tuttle, and Christopher Wright, and of Law Reference Librarians Patricia Brown, Ann Pascoe, Louis Rosen, and Nancy Strohmeyer. Linda Cahill provided invaluable IT support. This Article was made possible by the financial support of the Barry University School of Law Summer Research Grant.

I thank John Nowak, Juan Perea, Alexander Tsesis, and Michael Zimmer for the opportunity to present this Article at the Second Annual Loyola University Chicago Constitutional Law Colloquium, October 21-22, 2011.

I thank Charlie Stinson, Joe Schremmer, the editors, and the staff of the University of Kansas Law Review for their meticulous edits.

The author hereby licenses all readers to make unlimited photocopies of this Article. For permission to make other copies, please email the author.

1. 555 U.S. 460 (2009).

2. This Article uses the terms "object" and "symbol" interchangeably to refer generally to permanent structures, like monuments, as opposed to temporary holiday displays.

3. U.S. CONST. amend. I ("Congress shall make no law... abridging the freedom of speech.”).

4. Pleasant Grove City, 555 U.S. at 464-65. 
allows the government to select the message it wants to express. ${ }^{5}$ Applying the government speech doctrine, the Court upheld the city's actions against a Free Speech Clause challenge because the Free Speech Clause implicated government regulation of private speech, not government speech. ${ }^{6}$

Since the city embraced the Ten Commandments monument as its own speech, the question arose whether the city violated the Establishment Clause ${ }^{7}$ in displaying a religiously significant monument. The Court, however, did not address the constitutionality of the city's actions under the Establishment Clause because Summum did not raise that issue. ${ }^{8}$ In anticipation of this issue, Justice Scalia reassured the city that its victory would not "propel[] it from the Free Speech Clause frying pan into the Establishment Clause fire."

Fearing an Establishment Clause violation, some governmental bodies have sold religious monuments, objects, symbols, and the land under them to private parties when confronted with an Establishment Clause challenge. $^{10}$ Other governmental bodies have exchanged or

5. See id. ("[T] form of government speech and is therefore not subject to scrutiny under the Free Speech Clause.”).

6. See id. at 467.

7. U.S. CONST. amend. I (“Congress shall make no law respecting an establishment of religion....”).

8. See Pleasant Grove City, 555 U.S. at 482 (Scalia, J., concurring) (stating the parties argued the case under the Free Speech Clause, not the Establishment Clause). The city was essentially put in a position to "pick its poison" between the Free Speech Clause and the Establishment Clause. Chief Justice Roberts precisely framed the dilemma when he questioned counsel for Pleasant Grove City during oral arguments: “[Y]ou're really just picking your poison, aren’t you? I mean, the more you say that the monument is Government speech to get out of the first, free speech-the Free Speech Clause, the more it seems to me you're walking into a trap under the Establishment Clause.” Transcript of Oral Argument at 4, Pleasant Grove City, 555 U.S. 460 (2009) (No. 07-665); see also id. at 63 (oral argument by counsel for respondent) ("I do think that the-the city is a bit on the horns of a dilemma because it wants to have it both ways. It wants to be able to say this speech is governmental for purposes of blocking equal access rights; but not so governmental at that it's a big Establishment Clause problem.”).

9. Pleasant Grove City, 555 U.S. at 482 (Scalia, J., concurring).

10. See, e.g., Trunk v. City of San Diego, 629 F.3d 1099, 1103 (9th Cir. 2011) (attempting sale of Latin cross on public land to private association), cert. denied sub nom. Mount Soledad Mem'l Ass'n v. Trunk, 132 S. Ct. 2535 (2012); Mercier v. Fraternal Order of Eagles, 395 F.3d 693, 694 (7th Cir. 2005) (selling portion of city park with Ten Commandments monument to private service organization); Freedom From Religion Found. v. City of Marshfield, 203 F.3d 487, 489-90 (7th Cir. 2000) (selling Christ statue and underlying city land to private organization); Chambers v. City of Frederick, 373 F. Supp. 2d 567, 570 (D. Md. 2005) (selling parcel of land with Ten Commandments monument to a private organization following suit by ACLU); Kassandra J. Slaven, Comment, A Cross-Examination of the Establishment Clause and Boise's Table Rock Cross, 45 IDAHO L. REV. 651, 652-53 (2009) (discussing the sale of a sixty-foot cross erected on Table Rock in Boise). 
transferred the land beneath religious objects to private parties pursuant to federal law. Some transactions have included restrictive covenants that require the buyer maintain the religious object. ${ }^{11}$ Others have sold or transferred the religious object and its underlying land to the original donor without soliciting bids from other buyers ${ }^{12}$ or to a party despite the existence of a higher bid. ${ }^{13}$ In some circumstances, the religious object's original installation ${ }^{14}$ or the subsequent land transactions violated controlling law. ${ }^{15}$ Part II of this Article describes the circumstances in which governments have employed land sale, land transfer, and eminent domain to resolve Establishment Clause violations.

One such case of land privatization was Salazar v. Buono, where the federal government transferred to a private party public land in a national park, on which stood a Latin cross, in exchange for land from the private party. ${ }^{16}$ The Court, as a whole, did not consider whether the land transfer extricated the federal government from an Establishment Clause violation. ${ }^{17}$

This Article explores whether the transfer or sale of religious objects and the land underlying them to private hands saves the government from the Establishment Clause fire, a question left unanswered in Buono. $^{18}$ It provides an in-depth analysis of five cases in which governmental bodies resorted to privatizing public land to avoid violating the Establishment Clause and a broader doctrinal and theoretical critique of this practice. It argues that, under all proposed standards used in religious display cases, government disposition of

11. E.g., Buono v. Kempthorne (Buono IV), 527 F.3d 758, 771 (9th Cir. 2008), rev'd and remanded sub nom. Salazar v. Buono, 130 S. Ct. 1803 (2010). 490.

12. E.g., Trunk, 629 F.3d at 1103; Buono IV, 527 F.3d at 771; City of Marshfield, 203 F.3d at

13. E.g., Chambers, 373 F. Supp. 2d at 572.

14. See, e.g., Buono IV, 527 F.3d at 769 (constructing cross on federal land without proper permit).

15. See, e.g., Chambers, 373 F. Supp. 2d at 572 (selling land without following city land transaction guidelines).

16. 130 S. Ct. 1803, 1812 (2010) (plurality opinion). For an explanation of the complex litigation history of this case, see infra note 108.

17. See id. at 1815-16.

18. Cases involving disposition of religious objects can result from either a government assumption that the object itself will be found to violate the Establishment Clause or an actual judicial determination that such an object on government land indeed violates the Establishment Clause. This Article proceeds on the assumption that continued display of such an object on public land violates the Establishment Clause; thus, the purpose of this Article is to explore whether privatizing the land and religious object can end Establishment Clause violations. 
religious objects along with the public land beneath them violates the Establishment Clause.

The Court's Establishment Clause jurisprudence has been plagued with inconsistency ${ }^{19}$ because the Court has been "unwilling[] to be confined to any single test or criterion." 20 Consequently, this Article examines the constitutionality of such land transfers and sales under a number of competing Establishment Clause standards and theories. Because religious display cases are the most analogous to land disposition cases involving religious symbols, Part III provides a brief discussion of Establishment Clause standards used in religious display cases, namely the Lemon test, endorsement test, and Van Orden $v$. Perry's "21 “legal judgment” approach.

Both the Lemon and endorsement tests consider the government's purpose for engaging in the challenged action and the action's effect on the legally constructed reasonable observer. $^{22}$ To pass these tests, government action must be grounded in the pursuit of a secular purpose and must not endorse or disapprove of religion. ${ }^{23}$ Although the plurality in Van Orden found little use for the Lemon test, ${ }^{24}$ Part III concludes that the legal judgment approach, fostered by Justice Breyer, ${ }^{25}$ closely resembles the purpose and effect prongs of the Lemon and endorsement tests. Therefore, this Article proceeds by adopting the Lemon and endorsement tests as viable standards in light of Van Orden.

19. See Utah Highway Patrol Ass'n v. Am. Atheists, 132 S. Ct. 12, 13 (2011) (Thomas, J., dissenting from denial of cert.) (describing Establishment Clause jurisprudence as being "in shambles"); Lee v. Weisman, 505 U.S. 577, 619 (1992) (“Our precedents may not always have drawn perfectly straight lines.”); Mercier v. City of La Crosse, 305 F. Supp. 2d 999, 1010 (W.D. Wis. 2004) ("[T]he Court has struggled to set forth a consistent framework for addressing questions under the [E]stablishment [C]lause, as even the Court itself has recognized."), rev'd sub nom. Mercier v. Fraternal Order of Eagles, 395 F.3d 693 (7th Cir. 2005); Steven G. Gey, Religious Coercion and the Establishment Clause, 1994 U. ILL. L. REV. 463, 464 (1994) ("[T]he Court has left a constitutional muddle with a series of unsatisfactory and unclear standards and outcomes."); William P. Marshall, "We Know It When We See It": The Supreme Court and Establishment, 59 S. CAL. L. REV. 495, 497 (1986) ("The Court itself has acknowledged its own 'considerable internal inconsistency,' candidly admitting that it has 'sacrifice[d] clarity and predictability for flexibility,' and commentators have found the area hopelessly confused." (alteration in original) (footnote omitted)).

20. Lynch v. Donnelly, 465 U.S. 668, 679 (1984).

21. 545 U.S. 677 (2005).

22. See McCreary Cnty. v. ACLU of Ky., 545 U.S. 844, 864-66 (2005).

23. Lemon v. Kurtzman, 403 U.S. 602, 612-13 (1971) (articulating a three-prong test to evaluate challenges under the Establishment Clause); Lynch, 465 U.S. at 690 (O'Connor, J., concurring).

24. See Van Orden, 545 U.S. at 686 (plurality opinion).

25. See id. at 700 (Breyer, J., concurring). 
Part IV specifically considers the potential governmental purposes for the land disposition in determining the existence of a secular interest: providing memorials, avoiding a show of disrespect to religion, and avoiding Establishment Clause violations. The government has most frequently justified land privatization to preserve religious objects that were installed as a memorial or commemorative object, purportedly to promote civic-mindedness or recognize the heroism of veterans. Although these are laudable goals, these objectives are not uniquely connected to the religious symbol.

Additionally, the government has objected to removing the religious object for fear of showing disrespect toward religion. The government overlooks two problems when it makes this objection. One problem is that the government fails to show an equal concern about the disrespect shown to other religions or to nonbelievers when the government insists on keeping the religious symbol. The other problem is that the government, by using the symbol for a secular event, offends devout followers who revere the sacred symbols. Part IV argues that the purported government purposes are secondary to a religious interest because the government can achieve its objectives without resorting to land disposition.

Parts V and VI examine the effect that land disposition has on the "reasonable observer" who is aware of the history of the religious object and land disposition. ${ }^{26}$ Privatizing religious symbols and their surrounding land has the effect of advancing religion by securing the retention of religious objects through private land ownership. Further, restrictive covenants that require the private owner to maintain the symbol and reversionary clauses that allow the government to reclaim the land perpetuate state action and excessively entangle the government with religion. This Article concludes that governmental bodies cannot avoid the Establishment Clause fire by any means other than removing the religious object.

The intent of this Article is not to attack religion but to protect it by preventing governmental bodies from diluting the meaning of sacred religious symbols through their secularization. At the same time, the purpose of this Article is to argue for greater inclusiveness in public spaces for religious minorities and nonbelievers. By prohibiting government expression of religious preferences through land dispositions

26. See McCreary, 545 U.S. at 866 (noting that reasonable observers view objects within a historical context). 
that have been undertaken to preserve religious objects, which often reflect the majoritarian religion, religious believers and nonbelievers can equally participate in public spaces.

\section{THE LAY OF THE LAND}

In recent years, there has been a trend among governments to resort to land sale, eminent domain, and land transfer to resolve Establishment Clause violations. ${ }^{27}$ Because Establishment Clause jurisprudence is factdriven and context sensitive, ${ }^{28}$ this Part provides a detailed elaboration of the types of land disposition cases that implicate the Establishment Clause.

27. See, e.g., Trunk v. City of San Diego, 629 F.3d 1099, 1102 (9th Cir. 2011) (holding federal exercise of eminent domain to seize land on which a cross was erected violated Establishment Clause), cert. denied sub nom. Mount Soledad Mem'l Ass’n v. Trunk, 132 S. Ct. 2535 (2012); Mercier v. Fraternal Order of Eagles, 395 F.3d 693, 694 (7th Cir. 2005) (upholding sale of land beneath Ten Commandments monument against Establishment Clause challenge); Kong v. City \& Cnty. of San Francisco, 18 F. App’x 616, 617 (9th Cir. 2001) (unpublished opinion) (upholding city's auction of land beneath a cross as a resolution for Establishment Clause challenge); Freedom From Religion Found. v. City of Marshfield, 203 F.3d 487, 492-96 (7th Cir. 2000) (holding sale of Christ statue and land beneath it to private owner did not violate Establishment Clause, but visual conditions of park created a continuing perception of government endorsement in violation of the Establishment Clause); Chambers v. City of Frederick, 373 F. Supp. 2d 567, 573 (D. Md. 2005) (validating sale of land containing Ten Commandments monument to original donor organization); Summum v. Duchesne City, 340 F. Supp. 2d 1223, 1229 (D. Utah 2004) (upholding land sale to family that originally donated the Ten Commandments monument), rev'd, 482 F.3d 1263 (10th Cir. 2007), vacated, 129 S. Ct. 1523 (2009); Slaven, supra note 10, at 652-56 (discussing the sale of land under an illuminated sixty-foot cross erected on Table Rock in Boise).

28. See, e.g., Van Orden, 545 U.S. at 700 (Breyer, J., concurring) (stating that Establishment Clause analysis "must take account of context and consequences"); Santa Fe Indep. Sch. Dist. v. Doe, 530 U.S. 290, 315 (2000) ("Every government practice must be judged in its unique circumstances ....” (alteration in original) (quoting Lynch, 465 U.S. at 693-94 (O’Connor, J., concurring))); Lee v. Weisman, 505 U.S. 577, 597 (1992) (“Our Establishment Clause jurisprudence remains a delicate and fact-sensitive one....”); Cnty. of Allegheny v. ACLU Greater Pittsburgh Chapter, 492 U.S. 573, 629 (1989) (O’Connor, J., concurring) ("To be sure, the endorsement test depends on a sensitivity to the unique circumstances and context of a particular challenged practice....”); Mercier v. City of La Crosse, 305 F. Supp. 2d 999, 1018 (W.D. Wis. 2004) ("Establishment [C]lause cases are notoriously context sensitive."), rev'd sub nom. Mercier v. Fraternal Order of Eagles, 395 F.3d 693 (7th Cir. 2005). 


\section{A. Land Sales}

1. The Statue of Christ in Freedom From Religion Foundation v. City of Marshfield

One common approach used to resolve Establishment Clause claims involves land sales. In City of Marshfield, the city sold a statue of Christ and the surrounding land in response to an Establishment Clause challenge to the city's display of the statue. ${ }^{29}$ Although the bid met state requirements for public land sales ${ }^{30}$ and reflected fair market value, ${ }^{31}$ the city did not solicit any other bids ${ }^{32}$ and included in the sale a requirement that the land be used for a public park. ${ }^{33}$ After the sale, the statue remained in the public park, visible to drivers entering the city on a state highway. ${ }^{34}$ The city discontinued provision of electrical services to the park and erected a sign disclaiming the religious message of the statue. ${ }^{35}$

Subsequently, the plaintiffs complained that the sale was a sham to evade the Establishment Clause. ${ }^{36}$ The Seventh Circuit applied a presumption that "[a]bsent unusual circumstances, a sale of real property is an effective way for a public body to end its inappropriate endorsement of religion." 37 Because the restrictive covenant did not violate state property law, the Seventh Circuit concluded there were no extraordinary circumstances that would warrant voiding the sale. ${ }^{38}$ Although the court upheld the sale, it recognized the obvious religious message of the statue of Christ and found the government lacked a secular purpose for the statue. ${ }^{39}$

The court concluded that the sale did not change the nature of the park, which retained its public forum character even under private

29. Freedom From Religion Found. v. City of Marshfield, 203 F.3d 487, 489-90 (7th Cir. 2007). In 1959, the city accepted a white marble statue of Christ standing on a sphere with his arms open in prayer. $I d$. at 489 . The base of the statue bears the following inscription in twelve-inch block letters: "Christ Guide Us On Our Way." Id. For a picture of the statue, see FLICKR, http://www.flickr.com/photos/32441465@N00/172129898 (last visited Sept. 12, 2012).

30. City of Marshfield, 203 F.3d at 490.

31. Id. at 492

32. Id.

33. Id. at 490 .

34. Id. at 489. For a map of the statue's location, see id. at 500 fig.C.

35. Id. at 489-90.

36. Id. at 490 .

37. Id. at 491 .

38. Id. at 493.

39. Id. 
ownership. ${ }^{40}$ The court considered the historical use of the property as a public forum, its dedication for public purposes, the location of the statue in relation to the park, and the statue's visibility to the public. ${ }^{41}$ The property had been used as a public park and public forum, and the restrictive covenant requiring the continued public use reinforced the property's public forum status despite the sale. ${ }^{42}$ The statue's location and its lack of physical partition, coupled with the factors previously discussed, magnified the perception that the statue rested on public property. ${ }^{43}$ The disclaimer posted by the city did not mitigate this perception. $^{44}$ The court concluded, therefore, that a reasonable person would interpret the circumstances to convey governmental endorsement of a religious message. ${ }^{45}$

The Seventh Circuit, however, signaled that the city could remove the perception of continued government endorsement by constructing a fence or wall to separate the private property on which the statue now rests from the city's property. ${ }^{46}$ On remand, the district court ordered the city to erect a four-foot high fence around the monument. ${ }^{47}$

\section{The Ten Commandments Monument in Mercier v. Fraternal Order of Eagles}

Similarly, in Mercier, the city disposed of its land through a sale to cure an Establishment Clause challenge of a monument of the Ten Commandments that had rested in a public park for almost forty years. ${ }^{48}$ The city had dedicated the monument to commemorate the volunteer efforts of high school students during a flood. ${ }^{49}$

\footnotetext{
40. Id. at 494-95.

41. Id.

42. Id. at 494 .

43. Id. at 494-95.

44. Id. at 495.

45. Id. at 495-96.

46. Id. at 497 .

47. Freedom From Religion Found. v. City of Marshfield, No. 98-C-270-S, 2000 WL 767376, at $* 1$ (W.D. Wis. May 9, 2000). The district court also ordered a specific disclaimer sign. Id.

48. Mercier v. Fraternal Order of Eagles, 395 F.3d 693, 694 (7th Cir. 2005). The granite monument consisted of an inscription of the Ten Commandments, an eagle grasping the American flag, and the "all-seeing eye." Id. at 694-95. For photographs of the monument and a map of the park, see id. at 707-11. For additional description and history of a similar monument, see Books v. City of Elkhart, 235 F.3d 292, 294-96 (7th Cir. 2000).

49. Mercier, 395 F.3d at 696. Approximately 5,500 stone monuments of the Ten Commandments were dispersed throughout the United States as a part of a promotion of the movie
} 
Twenty years after its installation, the monument sparked controversy, and litigation ensued over whether the monument's presence violated the Establishment Clause. ${ }^{50}$ In an effort to remedy any Establishment Clause violations, three organizations made offers to the city: (1) the local Eagles chapter, which had originally donated the monument, offered to take back the monument and place it in a location visible to the public; (2) an Episcopal church offered to move the monument; and (3) the Freedom From Religion Foundation offered to move the monument to another location. ${ }^{51}$ Rather than accept the offers to move the monument, the city sold the monument and a parcel of land on which the monument rested to the local Eagles chapter. ${ }^{52}$ The city sought no other bids but sold the land for fair market value. ${ }^{53}$ Ten days prior to completion of the sale, litigation arose challenging the sale as violating the Establishment Clause by favoring the monument's religious message. $^{54}$

On review, the Seventh Circuit upheld the land sale. ${ }^{55}$ The court was persuaded by a number of factors: the city had a historical reason for retaining the monument; it was practical to sell the land to the Eagles due to the chapter's headquarters being located close to the monument; the land was not located near the seat of government; the monument was not located in a prominent part of the park; and the city and Eagles erected fencing and signs disclaiming government sponsorship. ${ }^{56}$ The court determined that the city had a secular purpose for both accepting the

The Ten Commandments. Chambers v. City of Frederick, 373 F. Supp. 2d 567, 569 (D. Md. 2005). Many cities displayed the Ten Commandments monoliths in public parks and near government buildings. Summum v. Duchesne City, 340 F. Supp. 2d 1223, 1225-26 (D. Utah 2004), rev'd, 482 F.3d 1263 (10th Cir. 2007), vacated, 129 S. Ct. 1523 (2009). For a sampling of the litigation that has ensued over monuments depicting the Ten Commandments, see infra note 123. See also Van Orden v. Perry, 545 U.S. 677, 688-90 (2005) (plurality opinion) (finding that historical meaning of the Ten Commandments prevented a monument from violating the Establishment Clause); Freedom From Religion Found. v. Zielke, 845 F.2d 1463, 1465 (7th Cir. 1998) (holding that plaintiffs lacked standing to challenge constitutionality of Ten Commandments monument in city park); Red River Freethinkers v. City of Fargo, 759 F. Supp. 2d 940, 943 (D.N.D. 2010) (holding that plaintiffs lacked standing to challenge constitutionality of Ten Commandments monument in city park).

50. See Mercier, 395 F.3d at 696 (describing a lawsuit in 1985, dismissed for lack of standing, that alleged the monument violated the Establishment Clause).

51. Id.

52. Id.

53. Id. at 697.

54. Id.

55. Id. at 705-06.

56. Id. at 703-04. 
monument to commemorate the flood volunteers and selling the parcel of land to avoid violating the Establishment Clause. ${ }^{57}$ Additionally, the court held that the sale "did not have the "primary or principal effect of advancing a religion.",58 The court concluded that a reasonable observer familiar with the history of the monument would understand the city's motivation for keeping the monument in the park and the practical solution of selling the monument to the Eagles, whose headquarters was conveniently located across from the park. ${ }^{59}$

\section{The Ten Commandments Monument in Chambers v. City of Frederick}

As in Mercier, in Chambers, the city received an identical monument of the Ten Commandments from the local Eagles chapter and similarly relied on selling public land to remedy an Establishment Clause challenge. ${ }^{60}$ When litigation over the monument commenced, the Eagles offered to purchase all or part of the memorial ground on which the monument rested. $^{61}$ At least eight other people or organizations informed the city of their interest to purchase the parcel of land. ${ }^{62}$ The city selected a buyer based on the bidder's ability to pay the fair market value of the land, willingness to comply with the covenants, and "ability to maintain the property."63 The city ultimately sold the parcel to the Eagles but retained ownership of another nearby monument. ${ }^{64}$

Although the city failed to comply with standards regulating the sale of city property and accepted the Eagles' lower bid, the district court found there were no "unusual circumstances surrounding the sale of the parcel of land so as to indicate an endorsement of religion." 65 Notwithstanding the first half of the monument's religious references, ${ }^{66}$

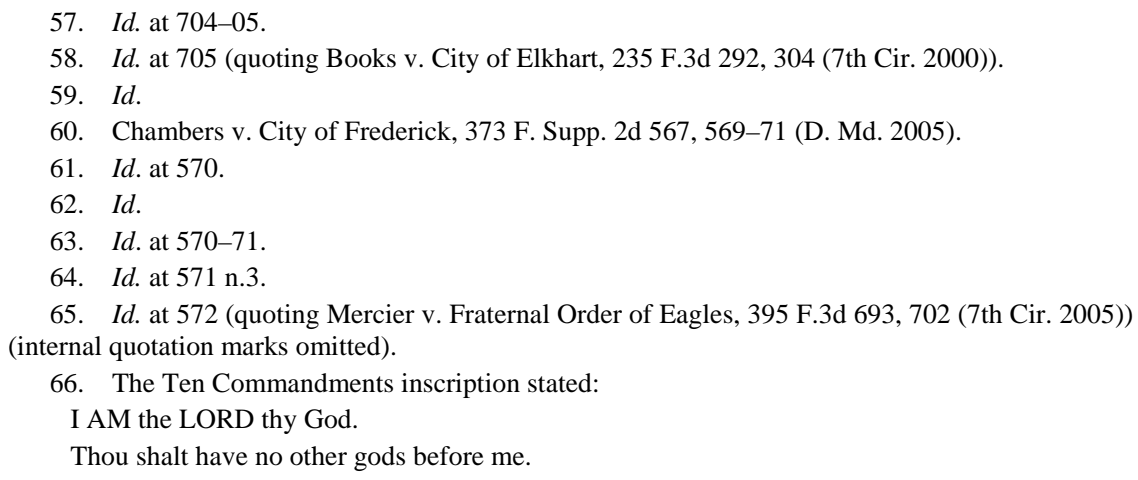


the court accepted the city's assertion that the monument had a secular purpose "to remind citizens not to bear false witness, to deal fairly and not covet other[s'] property, and to make the park into a haven of tranquility." ${ }^{67}$ Consequently, the court upheld the sale. ${ }^{68}$

\section{B. Eminent Domain: The Cross on Mount Soledad}

Another method of land disposition governments use in response to Establishment Clause concerns is the exercise of eminent domain. In Trunk v. City of San Diego, ${ }^{69}$ governmental bodies relied on both land sales and eminent domain to resolve litigation that arose over a Latin cross $^{70}$ on top of Mount Soledad. ${ }^{71}$ The cross stood forty-three feet high including its base, spanned twelve feet across, and weighed twenty-four tons $^{72}$-looming over thousands of drivers who used Interstate 5 and saw

Thou shalt not make to thyself any graven images.

Thou shalt not take the Name of the Lord thy God in vain.

Remember the Sabbath day, to keep it holy.

Honor thy father and thy mother, that thy days may be long upon the land which the Lord thy God giveth thee.

Thou shalt not kill.

Thou shalt not commit adultery.

Thou shalt not steal.

Thou shalt not bear false witness against thy neighbor.

Thou shalt not covet thy neighbor's house.

Thou shalt not covet thy neighbor's wife, nor his manservant, nor his maidservant, nor his cattle, nor anything that is thy neighbor's.

Books v. City of Elkhart, 235 F.3d 292, 296 (7th Cir. 2000).

67. Chambers, 373 F. Supp. 2d at 572-73 (internal quotation marks omitted).

68. Id. at 573 .

69. 629 F.3d 1099 (9th Cir. 2011), cert. denied sub nom. Mount Soledad Mem’l Ass’n v. Trunk, 132 S. Ct. 2535 (2012).

70. A Latin cross consists of a horizontal bar joined at the center by a longer vertical bar. Salazar v. Buono, 130 S. Ct. 1803, 1811-12 (2010) (plurality opinion).

71. Trunk, 629 F.3d at 1099. Many cities have accepted donations of crosses permanently erected on public land. See, e.g., Separation of Church \& State Comm. v. City of Eugene, 93 F.3d 617 (9th Cir. 1996) (describing a cross built on public land by private parties who later deeded the cross to the city).

There are other instances of cross displays on public land that have not been litigated. See, e.g., Slaven, supra note 10, at 654-55 (describing a two-ton, sixty-foot cross that was erected on Table Rock in Boise in 1956 and later sold, along with the land beneath it, upon impending litigation to the Boise Jaycees for \$100).

72. Trunk, 629 F.3d at 1103. For photographs of the cross and the site, see id. at 1126-27 app. A. 
[Vol. 61

it from miles away. ${ }^{73}$ In response to challenges over the cross, the city twice attempted to sell the cross and underlying land to a private group, but both sales were invalidated. ${ }^{74}$ The court invalidated the first land sale because the city's failure to solicit other bids showed a preference for Christianity and a desire to preserve the cross. ${ }^{75}$ The second sale failed because it was structured to give an advantage to bidders who desired to preserve the cross. ${ }^{76}$

Consequently, in 2004, the city proposed moving the cross to a church, but the proposal did not receive sufficient voter approval for a third sale. ${ }^{77}$ This failed initiative spurred local congressmen to add a provision to the 2005 budget requiring the federal government to accept the cross as a donation and designate it as a national veterans' memorial. ${ }^{78}$ The city government eventually submitted the issue to the voters. $^{79}$ After the ballot initiative received the required voter approval, yet another court enjoined the donation. ${ }^{80}$

As a result of this and other unresolved litigation, Congress intervened again in 2006. ${ }^{81}$ This time, Congress seized the memorial through eminent domain "in order to preserve a historically significant war memorial." ${ }^{2}$ Although the cross stood without any objects to distinguish it as a war memorial until the late 1990s, ${ }^{83}$ Congress declared that the site had served as a memorial for veterans for over fifty-two years. $^{84}$ Also, the "Act required the Department of Defense... to

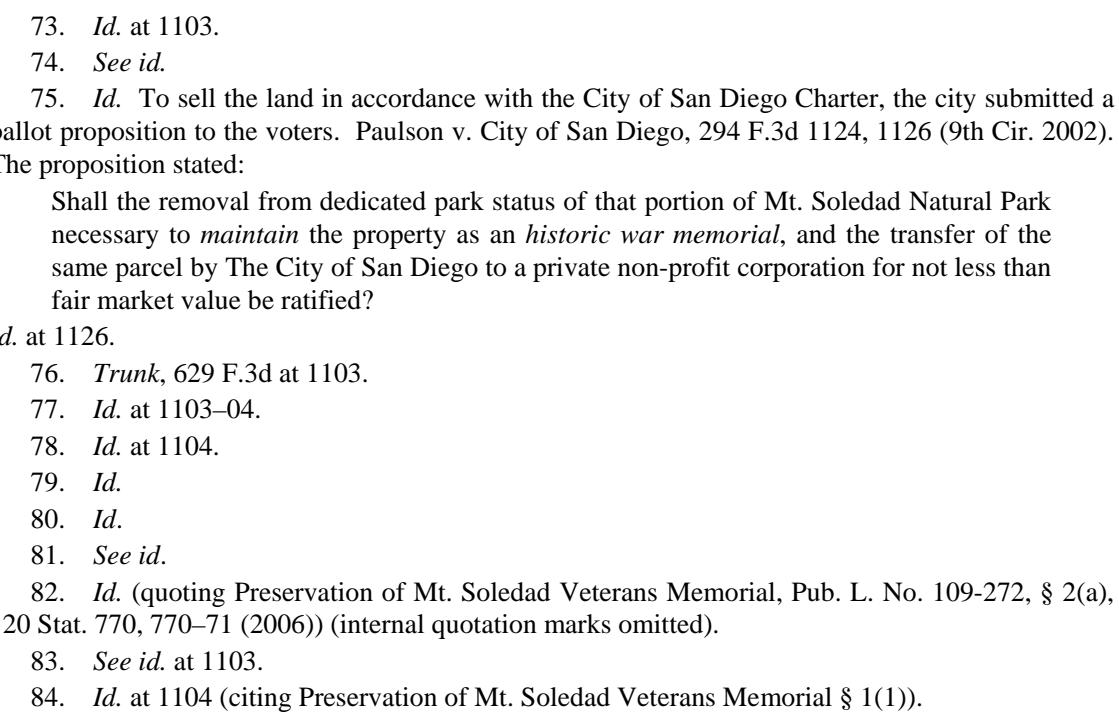


manage the property and enter a memorandum of understanding with the Association for the Memorial's 'continued maintenance.,",85

Following Congress's exercise of eminent domain, litigation arose that claimed the federal government's seizure violated the California and the United States Constitutions. ${ }^{86}$ The trial court granted summary judgment against the plaintiffs. ${ }^{87}$ On appeal, relying on legislative statements and the text of the act, the Ninth Circuit held that Congress had a secular purpose in acquiring the memorial. ${ }^{88}$ Nonetheless, the Ninth Circuit, after considering the cross's context, history, uses, and dominance, held that the memorial conveyed a message of government endorsement of religion. ${ }^{89}$

Trunk presents a unique case where two levels of government were involved in efforts to preserve a religious symbol, ${ }^{90}$ and where the methods pursued included both privatizing the land ${ }^{91}$ and retaining the land's public character. ${ }^{92}$ In light of the unprecedented, persistent congressional involvement in maintaining a religious symbol, it is curious that Congress thought conveyance or outright seizure of a sectarian symbol and underlying land from one level of government to another would extinguish an Establishment Clause challenge. After all, it was government ownership of the sectarian symbol and underlying land that sparked the controversy in the first place.

\section{Land Transfer: The Cross on Sunrise Rock, Mojave National Preserve}

A final method of addressing Establishment Clause challenges involves land transfers, which occurred in Salazar v. Buono. ${ }^{93}$ Buono involved a Latin cross that stood in the Mojave National Preserve, a

85. Id. at 1105 (quoting Preservation of Mt. Soledad Veterans Memorial § 2(c)). "The Association” refers to the Mount Soledad Memorial Association, a civic organization that installed the cross. Id. at 1103 .

86. Id. at 1105 .

87. Id.

88. See id. at 1108 .

89. Id. at 1125 .

90. See id. at 1103-04 (city and federal).

91. See id. at 1103 (selling land to private organization).

92. See id. at 1104 (donating land to federal government and using eminent domain to transfer land to federal government).

93. 130 S. Ct. 1803 (2010). 
national park spanning 1.6 million acres in southeastern California. ${ }^{94}$ The Veterans of Foreign Wars installed the cross on top of Sunrise Rock, along with wooden signs stating "The Cross, Erected in Memory of the Dead of All Wars," and "Erected 1934 by Members of Veterans of Foregin [sic] Wars, Death Valley post 2884."95 The original cross, as well as subsequent replacements, was installed without permission ${ }^{96}$ in contravention of park regulations. ${ }^{97}$ In its most recent form, the cross stood alone without any signs. ${ }^{98}$ The cross, standing less than eight feet high, ${ }^{99}$ was visible 100 yards away from a road passing through the preserve. ${ }^{100}$

In 1999, the National Park Service received a request to erect a Buddhist stupa ${ }^{101}$ on the outcropping near the cross. ${ }^{102}$ The Park Service denied the request, warning that "[a]ny attempt to erect a stupa will be in violation of Federal Law and [will] subject you to citation and/or arrest." 103 The National Park Service acknowledged that "[c]urrently there is a cross on [a] rock outcrop located on National Park Service lands" and committed in writing its "intention to have the cross removed." 104

Before undertaking the cross's removal, the National Park Service researched whether the cross and memorial site would qualify as a national historic place, worthy of preservation. ${ }^{105}$ But the Park Service concluded that the cross and memorial site were ineligible because the current cross was not the original, and the site had been used for religious purposes. ${ }^{106}$ In 2000, Congress responded to the National Park Service's anticipated removal of the cross by passing a law that prohibited the use

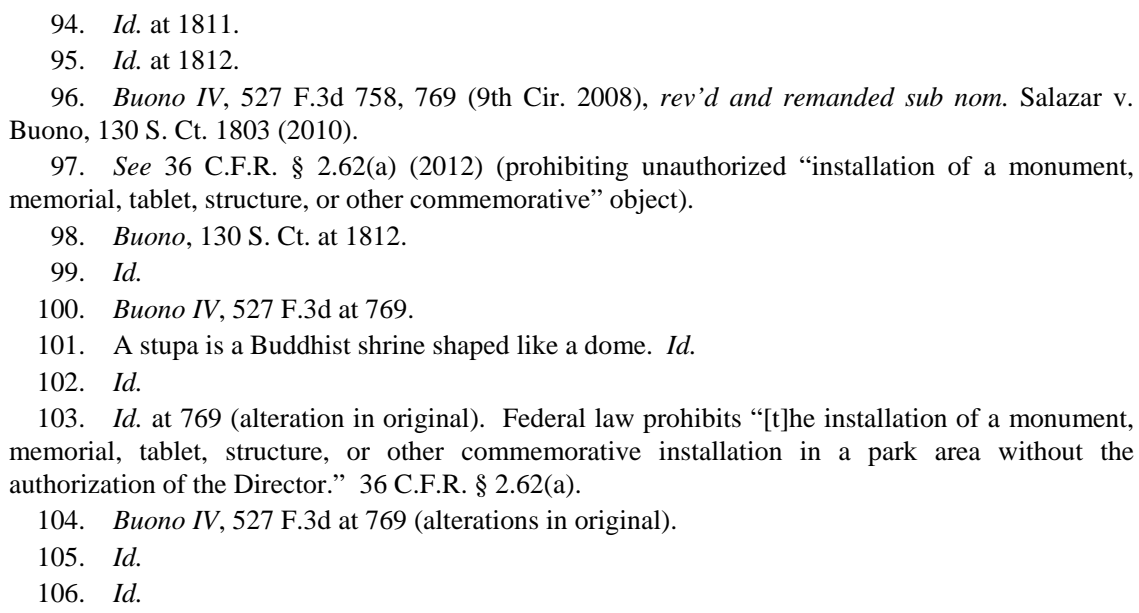


of federal funds to remove the cross. ${ }^{107}$ In 2001, Frank Buono, a former National Park Service employee, challenged the retention of the cross. ${ }^{108}$ In January 2002, during the pendency of the district court case, Congress designated the cross as a national memorial and required the Secretary of the Interior to use federal funds to "acquire a replica of the original memorial plaque and cross placed at the national World War I memorial."109

In July 2002, the district court found the cross violated the Establishment Clause and permanently enjoined the display of the cross. ${ }^{110}$ Three months after the district court's injunction, Congress passed another bill prohibiting use of federal funds "to dismantle national memorials commemorating United States participation in World War I."111 During the appeal of the case in September 2003, Congress passed a bill authorizing an exchange of the public land beneath the cross at Sunrise Rock for private land from Henry Sandoz, who had erected the current cross. ${ }^{112}$ This legislation required the recipient owner Veterans of Foreign Wars to maintain the property as a memorial, or the property would revert to the United States. ${ }^{113}$

When the case reached the Supreme Court, the Court's decision was limited to resolving, as Justice Breyer viewed it, “a very technical boring issue" 114 of whether the district court's injunction against implementation of the land exchange statute was proper. ${ }^{115}$ Because the government did

107. Id. (citing Consolidated Appropriations Act-FY 2001, Pub. L. No. 106-554, § 133, 114 Stat. 2763, 2763A-230 (2000)).

108. Buono v. Norton (Buono I), 212 F. Supp. 2d 1202, 1205, 1207 (C.D. Cal. 2002). As a result of four different cases, Buono's procedural history is complex. Buono I and Buono II centered on the constitutionality of the cross. The district court invalidated the display in Buono I, and the Ninth Circuit affirmed in Buono II, Buono v. Norton, 371 F.3d 543 (9th Cir. 2004). Buono III and Buono IV addressed the remedy; the district court in Buono III, Buono v. Norton, 364 F. Supp. 2d 1175 (C.D. Cal. 2005), and the Ninth Circuit in Buono IV, Buono v. Kempthorne, 527 F.3d 758 (9th Cir. 2008), concluded that Congress's land transfer failed to cure the Establishment Clause violation.

109. Buono IV, 527 F.3d at 770 (quoting Department of Defense and Emergency Supplemental Appropriations for Recovery from and Response to Terrorist Attacks on the United States Act, 2002, Pub. L. No. 107-117, § 8137(a)-(c), 115 Stat. 2230, 2278-79 (2002)).

110. Id.

111. Id. at 771 (quoting Department of Defense Appropriations Act, 2003, Pub. L. No. 107-248, § 8065(b), 116 Stat. 1519, 1551 (2002)).

112. Id. (quoting Department of Defense Appropriations Act, 2004, Pub. L. No. 108-87, § 8121(a)-(f), 117 Stat. 1054, 1100 (2003)).

113. Id.

114. Transcript of Oral Argument at 9, Salazar v. Buono, 130 S. Ct. 1803 (2010) (No. 08-472), available at http://supremecourt.gov/oral_arguments/argument_transcripts/08-472.pdf.

115. Buono, 130 S. Ct. at 1815-16 (plurality opinion). 
not appeal the ruling that the cross had the primary effect of advancing religion, res judicata prevented the Court's review of the underlying conclusion that the cross violated the Establishment Clause. ${ }^{116}$

Although there were six separate opinions, only three directly addressed the merits. ${ }^{117}$ Justice Kennedy, joined by the Chief Justice and, in part, by Justice Alito, sensitive to the government's dilemma between violating the injunction by maintaining the cross or showing disrespect for veterans by removing it, accorded legislative deference to the land transfer. ${ }^{118}$ While the plurality intimated that the land disposition adequately settled Establishment Clause concerns, ${ }^{119}$ it ultimately remanded the case to the district court to determine if knowledge of Congress's "policy of accommodation," manifested by the land transfer, would affect a reasonable observer's perception. ${ }^{120}$ Justice Alito, in his separate concurrence, was convinced that the government properly resolved Establishment Clause claims through the land transfer. $^{121}$ The dissent, however, was skeptical of the government's motive and argued that the land transfer was an inadequate Establishment Clause remedy. ${ }^{122}$

\section{STANDARDS FOR RELIGIOUS DISPLAYS}

Establishment Clause jurisprudence has often been described as "muddled" because there is no one prevailing standard and the Court's inquiry relies heavily on context. ${ }^{123}$ The Establishment Clause cases

116. See id. at 1815.

117. See id. at 1811, 1815-21; id. at 1821-24 (Alito, J., concurring); id. at 1828-45 (Stevens, J., dissenting).

118. See id. at 1817 (plurality opinion).

119. See id. at $1817-18$.

120. See id. at 1818-21.

121. Id. at 1821 (Alito, J., concurring).

122. See id. at 1830-31 (Stevens, J., dissenting). After twelve years of litigation, the district court approved a settlement agreement reached by the parties. The Veterans of Foreign Wars will receive the one acre of land surrounding the cross in exchange for land as specified in the land transfer act. The National Park Service agreed to erect a fence around the property and install signs to indicate it is private property. The National Park service will install a replica of the original plaque but may not install a replica of the cross. Land will not revert back to the United States. Although it is permitted to mention the memorial in its brochures, the National Park Service may not install other plaques or markers referring to the memorial. Settlement Agreement, Buono v. Salazar, No. 5:01-CV-00216-RT-SGL (C.D. Cal. Apr. 23, 2012), available at http://www.scribd. com/doc/91124039/Sunrise-Rock-Settlement-Agreement.

123. For example, the ambiguity in Establishment Clause jurisprudence and reliance on context has led to conflicting results regarding the Ten Commandments monument donated by the Fraternal 
involving religious displays lend the most analogous comparisons to land disposition cases because land dispositions often involve religious displays. In the context of religious display cases, the Court has applied three tests: Lemon test, endorsement test, and "legal judgment" approach.

\section{A. Lemon Test}

At the heart of the Court's tests in religious display cases are the questions of governmental purpose and the effect of governmental action. In Lemon v. Kurtzman, this inquiry was encompassed in a three-

Order of the Eagles to various cities, even though the monuments are identical. See Susanna Dokupil, "Thou Shall Not Bear False Witness": "Sham" Secular Purposes in Ten Commandments Displays, 28 HARV. J.L. \& PUB. POL’y 609, 640 (2005); see also Green v. Haskell Cnty. Bd. of Comm'rs, 568 F.3d 784, 779-804 (10th Cir. 2009) (rejecting a presumption of unconstitutionality of Ten Commandments monument, but concluding that the monument had an effect of government endorsement, without directly addressing whether government had a secular purpose); Card v. City of Everett, 520 F.3d 1009, 1019-21 (9th Cir. 2008) (concluding city had secular purpose in displaying Ten Commandments monument and no violation of Establishment Clause); ACLU Neb. Found. v. City of Plattsmouth, 419 F.3d 772, 778 (8th Cir. 2005) (en banc) (upholding Ten Commandments monument as not contravening the Establishment Clause); Adland v. Russ, 307 F.3d 471, 489-90 (6th Cir. 2002) (affirming district court's finding that Ten Commandments monument display advanced a religious purpose); Summum v. City of Ogden, 297 F.3d 995, 1000 n.3 (10th Cir. 2002) ("[T]he fact that Anderson considered an identical Ten Commandments Monument is not necessarily controlling. . . . Nor, particularly in light of Allegheny's fact-intensive inquiry, does the fact that Salt Lake City's Ten Commandments Monument [in Anderson] did not have an improper effect establish that the City of Ogden's Monument was not likely to have such an improper effect.”); Ind. Civil Liberties Union v. O’Bannon, 259 F.3d 766, 771-73 (7th Cir. 2001) (invalidating display of Ten Commandments monument because of religious purpose and effect of conveying a religious message); Books v. City of Elkhart, 235 F.3d 292, 306-07 (7th Cir. 2000) (concluding that Ten Commandments monument was displayed for a religious purpose and that it advanced religion); Anderson v. Salt Lake City Corp., 475 F.2d 29, 34 (10th Cir. 1973) (accepting the Ten Commandments display for the secular purpose of reflecting the history of United States and Utah laws and finding no Establishment Clause violation), abrogated by Van Orden v. Perry, 545 U.S. 677 (2005), and McCreary Cnty. v. ACLU of Ky., 545 U.S. 855 (2005); ACLU v. Bd. of Comm'rs, 444 F. Supp. 2d 805, 815-16 (N.D. Ohio 2006) (finding secular purpose and no governmental endorsement of religion); Twombly v. City of Fargo, 388 F. Supp. 2d 983, 983 (D.N.D. 2005) (finding secular purpose in display of Ten Commandments monument); Chambers v. City of Frederick, 373 F. Supp. 2d 567, 573 (D. Md. 2005) (finding secular purpose and no impermissible advancement of religion in Ten Commandments display); Russelburg v. Gibson Cnty., No. 3:03-CV-149-RLY-WGH, 2005 WL 2175527, at *2 (S.D. Ind. Sept. 7, 2005) (upholding Ten Commandments display in light of Van Orden); Summum v. Duchesne City, 340 F. Supp. 2d 1223, 1226 (D. Utah 2004) ("The outcome of these Establishment Clause challenges varied from court to court and circuit to circuit.”), rev’d, 482 F.3d 1263 (10th Cir. 2007), vacated, 555 U.S. 1210 (2009); Christian v. Grand Junction, No. 01-CV-685, 2001 WL 34047958, at *5 (D. Colo. June 27, 2001) (upholding Ten Commandments display by denying preliminary injunction); Kimberly v. Lawrence Cnty., 119 F. Supp. 2d 856, 873 (S.D. Ind. 2000) (invalidating Ten Commandments display as violation of Establishment Clause); State v. Freedom From Religion Found., 898 P.2d 1013, 1026-27 (Colo. 1995) (upholding Ten Commandments display). 
part test: "First, the statute must have a secular legislative purpose; second, its principal or primary effect must be one that neither advances nor inhibits religion; finally, the statute must not foster 'an excessive government entanglement with religion." "'24 Using this test, the Lemon Court invalidated state aid to church-related schools because although the state had a secular purpose for providing aid to parochial schools, ${ }^{125}$ the regulations excessively entangled the state through comprehensive state surveillance needed to ensure that the subsidy would be used only for secular education. ${ }^{126}$ Although the Lemon test has its critics ${ }^{127}$ and has at times been completely disregarded, ${ }^{128}$ it has not been overruled. ${ }^{129}$

\section{B. Endorsement Test}

The Lemon test was eventually refashioned by Justice O'Connor into the endorsement test. The endorsement test focuses on whether the

124. 403 U.S. 602, 612-13 (1971) (citations omitted). For an excellent discussion of secular purpose, see Andrew Koppelman, Secular Purpose, 88 VA. L. REV. 87, 94 (2002) (clarifying the meaning of secular purpose and responding to objections raised against the secular purpose requirement).

125. Lemon, 403 U.S. at 613.

126. Id. at 616 .

127. See, e.g., Cnty. of Alleghney v. ACLU Greater Pittsburgh Chapter, 492 U.S. 573, 655-56 (Kennedy, J., concurring in part and dissenting in part) (providing cases that criticize the Lemon test).

128. Justice Thomas has catalogued the Court's treatment of the Lemon test:

Some of our cases have simply ignored the Lemon or Lemon/ endorsement formulations. See, e.g., Zelman v. Simmons-Harris, 536 U.S. 639, 122 S.Ct. 2460, 153 L.Ed.2d 604 (2002); Good News Club v. Milford Central School, 533 U.S. 98, 121 S.Ct. 2093, 150 L.Ed.2d 151 (2001); Marsh v. Chambers, 463 U.S. 783, 103 S.Ct. 3330, 77 L.Ed.2d 1019 (1983). Other decisions have indicated that the Lemon /endorsement test is useful, but not binding. Lynch v. Donnelly, 465 U.S. 668, 679, 104 S.Ct. 1355, 79 L. Ed. 2d 604 (1984) (despite Lemon's usefulness, we are "unwillin[g] to be confined to any single test or criterion in this sensitive area”); Hunt v. McNair, 413 U.S. 734, 741, 93 S. Ct. 2868, 37 L.Ed.2d 923 (1973) (Lemon provides “no more than helpful signposts”). Most recently, in Van Orden, 545 U.S. 677, 125 S.Ct. 2854, a majority of the Court declined to apply the Lemon /endorsement test in upholding a Ten Commandments monument located on the grounds of a state capitol. Yet in another case decided the same day, McCreary County v. American Civil Liberties Union of Ky., 545 U.S. 844, 859-866, 125 S.Ct. 2722, 162 L.Ed.2d 729 (2005), the Court selected the Lemon /endorsement test with nary a word of explanation and then declared a display of the Ten Commandments in a courthouse to be unconstitutional. See also Van Orden, supra, at 692, 125 S.Ct. 2854 (SCALIA, J., concurring) ("I join the opinion of THE CHIEF JUSTICE because I think it accurately reflects our current Establishment Clause jurisprudence-or at least the Establishment Clause jurisprudence we currently apply some of the time”).

Utah Highway Patrol Ass'n v. Am. Atheists, 132 S. Ct. 12, 14-15 (2011) (Thomas, J., dissenting from denial of cert.).

129. Lamb’s Chapel v. Ctr. Moriches Union Free Sch. Dist., 508 U.S. 384, 395 n.7 (1993). 
government acts in a manner that endorses or disapproves of religion. ${ }^{130}$ Under this test, a government act violates the Establishment Clause if the government's "actual purpose is to endorse or disapprove of religion[,] ... [and if,] irrespective of government's actual purpose, the practice under review in fact conveys a message of endorsement or disapproval." 131

The endorsement test is concerned with the perception of government endorsement as seen by a reasonable observer who is "more informed than the casual passerby."132 The test does not focus on "the perceptions of particular individuals or saving isolated nonadherents from the discomfort of viewing symbols of a faith to which they do not subscribe."133 Additionally, by not focusing on "the actual perception of individual observers, who naturally have differing degrees of knowledge," the endorsement test, as Justice O’Connor argued, “creates a more collective standard to gauge "the "objective" meaning of the [government's] statement in the community.",134 Justice O’Connor's reasonable person is derived from tort law and embodies a person "who 'is not to be identified with any ordinary individual, who might occasionally do unreasonable things,' but is 'rather a personification of a community ideal of reasonable behavior, determined by the [collective] social judgment.",135 The endorsement inquiry does not ask "whether there is any person who could find an endorsement of religion, whether some people may be offended by the display, or whether some reasonable person might think [the state] endorses religion."136

130. See Lynch v. Donnelly, 465 U.S. 668, 688 (1984) (O’Connor, J., concurring) (“Focusing on institutional entanglement and endorsement or disapproval of religion clarifies the Lemon test as an analytical device.”).

131. Id. at 690 .

132. Capitol Square Review \& Advisory Bd. v. Pinette, 515 U.S. 753, 779 (1995) (O’Connor, J., concurring).

133. Id

134. Id. (alteration in original) (quoting Lynch, 465 U.S. at 690).

135. Id. (alteration in original) (quoting W. KeETON ET AL., Prosser \& KEETON ON TORTS 175 (5th ed. 1984)).

136. Id. at 780 (alteration in original) (quoting Am. United for Separation of Church \& State v. City of Grand Rapids, 980 F.2d 1538, 1544 (6th Cir. 1992)) (internal quotation marks omitted).

Evaluating the effect of the government's action from the reasonable observer's perspective has prompted much criticism. Scholars have noted that the reasonable observer standard has led to inconsistent rulings in the lower courts. See, e.g., Jesse Choper, The Endorsement Test: Its Status and Desirability, 18 J.L. \& PoL. 499, 513-14 (2002) (discussing the manipulability of the reasonable observer construct and that the outcome of cases depends upon the characteristics attributed to the reasonable observer). Professor Steven Smith has pointed out that "invoking a fictional observer as the arbiter of meaning merely turns disputes about 'what the law means' into more byzantine 
Some have interpreted the endorsement test as a separate or alternative test to the Lemon test, while others have understood it as part of the Lemon test. ${ }^{137}$ For practical ease, this Article applies the endorsement test in conjunction with the Lemon test.

\section{C. “Legal Judgment” Approach}

Another approach to resolving cases involving religious symbolism evolved in Van Orden v. Perry, where the Court reviewed the constitutionality of a monument of the Ten Commandments displayed on a state capitol's public grounds that contained sixteen additional

disputes about just what sort of character the fictional observer is, or about what this fictional character would perceive." Steven D. Smith, Expressivist Jurisprudence and the Depletion of Meaning, 60 MD. L. REV. 506, 561 (2001).

For example, it is unclear if the reasonable observer is a member of the mainstream religion or minority religion or atheist. The reasonable observer's religious affiliation may change the analysis of the effect of the government's actions. "[I]f this individual is a member of the religious (or political) mainstream, there is too great a risk that the perspective 'will be inadequately sensitive to the impact of government actions on religious minorities, thereby in effect basing the protection of religious minorities on the judgment of the very majority that is accused of infringing the minority's religious autonomy.'” Choper, supra, at 511 (quoting, Note, Developments in the Law: Religion and the State, 100 HARV. L. REV. 1606, 1648 (1987)).

Additionally, Justice Stevens has criticized the reasonable person as conceptualized by Justice O’Connor:

[H]er reasonable person is a legal fiction, a personification of a community ideal of reasonable behavior, determined by the [collective] social judgment. The ideal human Justice O'Connor describes knows and understands much more than meets the eye. Her "reasonable person" comes off as a well-schooled jurist, a being finer than the tort-law model. With respect, I think this enhanced tort-law standard is singularly out of place in the Establishment Clause context. It strips of constitutional protection every reasonable person whose knowledge happens to fall below some "ideal" standard.

Pinette, 515 U.S. at 800 n.5 (Stevens, J., dissenting) (alteration in original) (citation omitted) (internal quotation marks omitted). “Instead of protecting only the 'ideal' observer,” Justice Stevens advocates "extend[ing] protection to the universe of reasonable persons and ask[ing] whether some viewers of the religious display would be likely to perceive a government endorsement.” Id.

137. Mark Strasser, Establishing the Pledge: On Coercion, Endorsement, and the Marsh Wild Card, 40 InD. L. REv. 529, 556 (2007); see also, Trunk v. City of San Diego, 629 F.3d 1099, 1106 (9th Cir. 2010) ("In recent years, the Supreme Court essentially has collapsed [Lemon's] last two prongs to ask 'whether the challenged governmental practice has the effect of endorsing religion."” (quoting Access Fund v. U.S. Dep’t of Agric., 499 F.3d 1036, 1043 (9th Cir. 2007))), cert. denied sub nom. Mount Soledad Mem’l Ass’n v. Trunk, 132 S. Ct. 2535 (2012); Mellen v. Bunting, 327 F.3d 355, 371 (4th Cir. 2003) ("[W]e then apply the Lemon criteria, treating the endorsement test as a refinement of Lemon's second prong.”); Adland v. Russ, 307 F.3d 471, 479 (6th Cir. 2002) ("We treat the endorsement test as a refinement of the second Lemon prong.”); LESLIE C. GRIFFIN, LAW AND RELIGION: CASES AND MATERIALS 62 (2d ed. 2010) (introducing "the endorsement and coercion tests as alternatives to Lemon”). 
monuments and twenty-one historical markers. ${ }^{138}$ Adding to the confusion in Establishment Clause jurisprudence, the plurality believed the Lemon test was "not useful" in this particular circumstance ${ }^{139}$ and held that the monument did not violate the Establishment Clause. ${ }^{140}$ The plurality dismissed the Lemon test because of the passive nature of the monument and the country's history of governmental recognition of the influence of religion in American life. ${ }^{141}$

Justice Breyer's concurrence, which controlled in this plurality opinion, shed little light on the proper approach courts should use for reviewing religious symbolism cases. In his concurrence, Justice Breyer tried to distance himself from the Lemon and endorsement tests by "rely[ing] less upon a literal application of any particular test"142 and espousing "the exercise of legal judgment." ${ }^{\text {"143 }}$ His legal judgment approach included "reflect[ing] and remain[ing] faithful to the underlying purposes of the Clauses and ... tak[ing] account of context and consequences measured in light of those purposes."

\section{Which Test is Controlling?}

The Lemon and endorsement tests remain viable standards for evaluating religious display cases. Although Van Orden declined to apply these tests, McCreary County v. American Civil Liberties Union of Kentucky, ${ }^{145}$ which was decided on the same day, not only embraced the three-factor Lemon test ${ }^{146}$ but also reinvigorated it with a more demanding standard. ${ }^{147}$ In McCreary, the Court invalidated the display

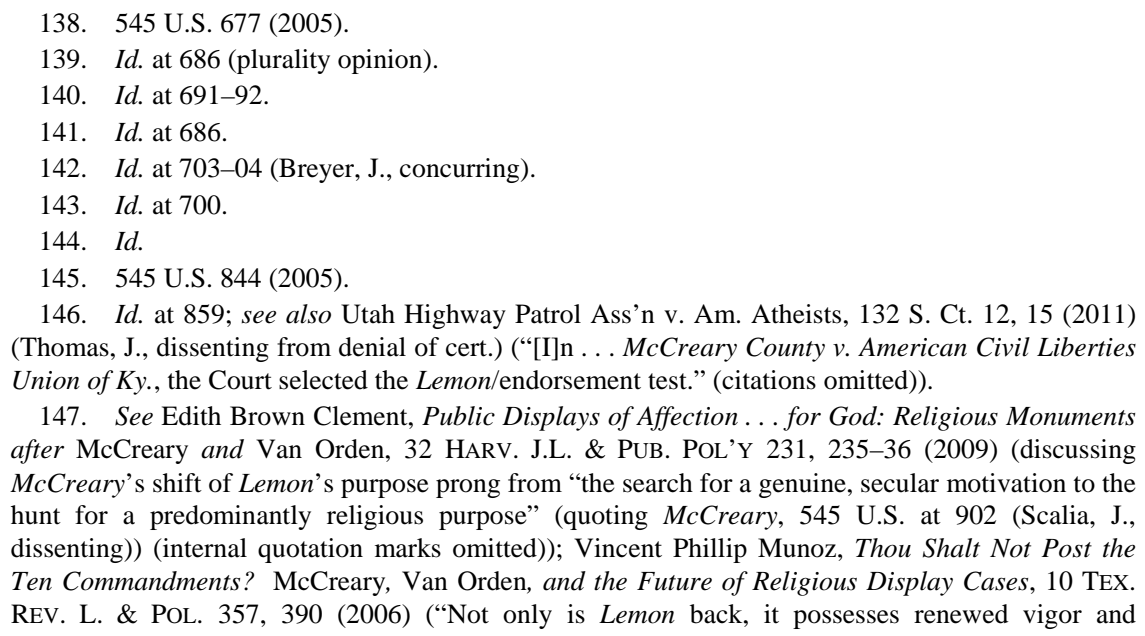
Union of Ky., the Court selected the Lemon/endorsement test." (citations omitted)).

147. See Edith Brown Clement, Public Displays of Affection ... for God: Religious Monuments after McCreary and Van Orden, 32 HARV. J.L. \& PUB. POL’y 231, 235-36 (2009) (discussing McCreary's shift of Lemon's purpose prong from "the search for a genuine, secular motivation to the hunt for a predominantly religious purpose" (quoting McCreary, 545 U.S. at 902 (Scalia, J., dissenting)) (internal quotation marks omitted)); Vincent Phillip Munoz, Thou Shalt Not Post the Ten Commandments? McCreary, Van Orden, and the Future of Religious Display Cases, 10 Tex. REV. L. \& PoL. 357, 390 (2006) ("Not only is Lemon back, it possesses renewed vigor and 
of the Ten Commandments posted on courthouse walls because the government, despite having modified the display several times to include a broader array of historical documents, acted with a predominately religious purpose. ${ }^{148}$ Rather than discarding Lemon, as the dissent urged, McCreary appeared to impose a heightened Lemon standard: "If the government's proffered secular purpose is not genuine, then the government has no secular purpose at all.",149

Recently, the Buono plurality relied on the endorsement test, as evidenced by its urging the district court to consider the reasonable observer's perception in light of Congress's accommodation policy. ${ }^{150}$ In that case, Justice Kennedy specifically "require[d] the hypothetical construct of an objective observer who knows all of the pertinent facts and circumstances surrounding the symbol and its placement."151

Even after Van Orden, most appellate courts continue to apply Lemon's three-prong test. ${ }^{152}$ Among the sixteen religious display cases decided by the federal courts of appeals since Van Orden, ${ }^{153}$ "only two

meaning.”).

148. McCreary, 545 U.S. at 881.

149. Id. at 901 (Scalia, J., dissenting).

150. See Salazar v. Buono, 130 S. Ct. 1803, 1819-21 (2010) (plurality opinion).

151. Id. at 1819-20. It is possible that Justice Kennedy alluded to the reasonable observer because of the district court's adoption of this construct, but he did not depart from or criticize the lower court's reliance on the reasonable observer construct.

152. Clement, supra note 147, at 246; see also Douglas G. Smith, The Constitutionality of Religious Symbolism after McCreary and Van Orden, 12 TEX. REV. L. \& POL. 93 (2007) (surveying federal circuit court responses to Van Orden and McCreary in religious symbolism cases).

153. See Johnson v. Poway Unified Sch. Dist., 658 F.3d 954, 972 (9th Cir. 2011) (applying Lemon test); ACLU of Ohio Found. v. DeWeese, 633 F.3d 424, 431 (6th Cir. 2011) (stating that Lemon remains the law governing Establishment Clause cases); Trunk v. City of San Diego, 629 F.3d 1099, 1107 (9th Cir. 2011) (noting that application of either test would yield same result), cert. denied sub nom. Mount Soledad Mem’l Ass'n v. Trunk, 132 S. Ct. 2535 (2012); Am. Atheists v. Davenport, 637 F.3d 1095, 1117 (10th Cir. 2010) (en banc) (stating that Establishment Clause analysis remains the three-part Lemon test); ACLU of Ky. v. Grayson Cnty., 591 F.3d 837, 844-48 (6th Cir. 2010) (applying modified version of Lemon test); Cooper v. U.S. Postal Serv., 577 F.3d 479, 494 (2d Cir. 2009) (stating that Lemon test is still primary means of evaluating Establishment Clause challenges to religious displays); Green v. Haskell Cnty. Bd. of Comm'rs, 568 F.3d 784, 796 (10th Cir. 2009) (stating that court was obliged to follow Lemon test as refined by Justice O’Connor); Winbaum v. City of Las Cruces, 541 F.3d 1017, 1030 (10th Cir. 2008) (stating that Lemon test remains touchstone for Establishment Clause analysis); Card v. City of Everett, 520 F.3d 1009, 1013 (9th Cir. 2008) (accepting application of Lemon test generally but not applying it in instant circumstances); Buono v. Kempthorne, 502 F.3d 1069, 1073 (9th Cir. 2007) (reviewing original trial court litigation that was decided under Lemon test), amended and superseded on denial of reh'g by 527 F.3d 758 (9th Cir. 2008), rev'd and remanded sub nom. Salazar v. Buono, 130 S. Ct. 1803 (2010); Access Fund v. U.S. Dep’t of Agric., 499 F.3d 1036, 1042 (9th Cir. 2007) (stating that Lemon test "remains the benchmark to gauge whether a particular government activity violates the 
have expressly declined to apply Lemon, and both did so on extremely narrow grounds." 154

Perhaps courts continue to rely on the Lemon and endorsement tests after Van Orden because Van Orden's own analysis resembles the inquiry encompassed in these tests. ${ }^{155}$ Despite his professed resistance to following Lemon, Justice Breyer's Van Orden analysis, in practical effect, shows consideration of the purpose and effect factors found in the Lemon and endorsement tests. ${ }^{156}$

First, Justice Breyer's evaluation of context and history ${ }^{157}$ is akin to the Lemon and endorsement tests' effects prong, which also takes into account history and context. He rested his conclusion that the monument's display on public land was constitutional on the display's context - the physical setting of the monument-and history. ${ }^{158}$ The monument's location in a park with sixteen secular monuments and twenty-one historical markers negated any implication of religious activity. ${ }^{159}$ Justice Breyer also found it significant that the display

Establishment Clause”); Staley v. Harris Cnty., 461 F.3d 504, 515-16 (5th Cir. 2006) (stating that the "Lemon test remains the benchmark for reviewing the constitutionality of a monument of public property”), dismissed as moot en banc, 485 F.3d 305 (5th Cir. 2007); Selman v. Cobb Cnty. Sch. Dist., 449 F.3d 1320, 1327 (11th Cir. 2006) (reviewing the district court's application of the Lemon test); Skoros v. City of New York, 437 F.3d 1, 16 (2d Cir. 2006) (applying the Lemon test); ACLU of Ky. v. Mercer Cnty., 432 F.3d 624, 636 (6th Cir. 2005) (continuing to apply the Lemon test following recent Supreme Court decisions); ACLU Neb. Found. v. City of Plattsmouth, 419 F.3d 772, 778 n.8 (8th Cir. 2005) (en banc) (expressly rejecting Lemon test); Soc'y of Separationists v. Pleasant Grove City, 416 F.3d 1329, 1241 (10th Cir. 2005) (reversing and remanding for further factual inquiry following recent Supreme Court decisions); O’Connor v. Washburn Univ., 416 F.3d 1216, 1224 (10th Cir. 2005) (finding that Lemon test remains law until overruled by Supreme Court and applying Lemon test with Justice O'Connor's endorsement test).

154. Clement, supra note 147, at 247 (footnote omitted).

155. See B. Jessie Hill, Putting Religious Symbolism in Context: A Linguistic Critique of the Endorsement Test, 104 MicH. L. REV. 491, 501-02 (2005) (pointing out that Justice Breyer in Van Orden used "an analysis that is functionally equivalent to the endorsement inquiry").

156. Trunk, 629 F.3d at 1107 (9th Cir. 2010) ("Notably, this inquiry does not dispense with the Lemon factors, but rather retains them as 'useful guideposts.”' (quoting Van Orden v. Perry, 545 U.S. 677, 700 (2005) (Breyer, J., concurring))).

157. See Van Orden, 545 U.S. at 701-02 (Breyer, J., concurring) (examining the use of the Ten Commandments' text and the context of the display).

158. See id. at 701-03.

159. Id. at 702. The other monuments included Heroes of the Alamo, Hood's Brigade, Confederate Soldiers, Volunteer Fireman, Terry's Texas Rangers, Texas Cowboy, SpanishAmerican War, Texas National Guard, Tribute to Texas School Children, Texas Pioneer Woman, The Boy Scouts' Statue of Liberty Replica, Pearl Harbor Veterans, Korean War Veterans, Soldiers of World War I, Disabled Veterans, and Texas Peace Officers. Id. at 681 n.1 (plurality opinion). 
existed for forty years without being challenged. ${ }^{160}$ Second, he determined that the monument conveyed a religious and secular moral message $^{161}$ that suggested a secular purpose for the display, which corresponded to the purpose prong of the Lemon and endorsement tests. Therefore, because a majority of courts have relied on the Lemon and endorsement tests after Van Orden, and Van Orden itself does not significantly depart from them, this Article applies these tests to determine the constitutionality of land dispositions involving religious symbols.

\section{GOVERNMENT PURPOSE}

Both the Lemon and endorsement tests require inquiry into legislative purpose to determine if government actions comport with the Establishment Clause. ${ }^{162}$ Various purposes have been presented to explain disposition of public land including the maintenance of memorials and commemorative objects, the avoidance of showing disrespect to religion, and the avoidance of Establishment Clause violations. These purposes, however, can be challenged as disingenuous and unnecessary and can result in outright circumvention of the law.

\section{A. Method of Determining Legislative Purpose}

Determining the government's purpose for disposing of public land is essential to deciding the constitutionality of such acts. Courts have discerned legislative purpose from "readily discoverable fact, without any judicial psychoanalysis of a drafter's heart of hearts."163 These facts are evaluated through the perspective of an objective observer who considers the "text, legislative history, and implementation of the statute, or comparable official act." 164 This objective observer is not only familiar with the government's past actions but also "competent to learn what history has to show."165 The Court has considered textual changes

\footnotetext{
160. See id. at 702-03 (Breyer, J., concurring).

161. See id. at 701-03 (referring to the "Commandments' role in shaping civic morality as part of [the Fraternal Order of the Eagles'] efforts to combat juvenile delinquency”).

162. For a critique of the motivational approach in religion cases, see John Hart Ely, Legislative and Administrative Motivation in Constitutional Law, 79 YALE L.J. 1205, 1313-27 (1970).

163. McCreary Cnty. v. ACLU of Ky., 545 U.S. 844, 862 (2005).

164. Id. (quoting Santa Fe Indep. Sch. Dist. v. Doe, 50 U.S. 290, 308 (2000)) (internal quotation marks omitted).

165. Id. at 866 (citing Santa Fe, 50 U.S. at 308).
} 
between prior and subsequent legislation, ${ }^{166}$ public comments made by the bill's sponsor, ${ }^{167}$ and the government action itself $^{168}$ to arrive at a commonsense conclusion about the government's purpose. ${ }^{169}$

Although the Court generally accords deference to the stated legislative purpose, "the secular purpose required has to be genuine, not a sham, and not merely secondary to a religious objective." Graham, the Court found a religious objective in legislation requiring the posting of the Ten Commandments in schools. ${ }^{171}$ Notwithstanding the government's avowed secular purpose for posting the Ten Commandments to illustrate their legal influence, the sacred nature of the Ten Commandments led the Court to conclude the "pre-eminent purpose" for the government's action was "plainly religious."172 Also, in School District of Abington Township v. Schempp, the professed secular purpose of providing education in music and literature did not alter the Court's conclusion that there was a religious objective behind laws requiring students to recite the Lord's Prayer and Bible readings. ${ }^{173}$

Similarly, in Edwards $v$. Aguillard, the Court rejected the government's purported secular purpose behind a law prohibiting the teaching of evolution unless accompanied with instruction on creation science. ${ }^{174}$ While acknowledging the deference accorded to the government's stated secular purpose, the Court insisted that the government's articulation "of such purpose be sincere and not a sham." ${ }^{\prime 75}$ The Court concluded that the government's purpose was to advance a religious viewpoint, ${ }^{176}$ because if the government had truly been interested in providing comprehensive education, it would have

166. Wallace v. Jaffree, 472 U.S. 38, 58-60 (1985) (inferring purpose from textual changes in school prayer statute).

167. Edwards v. Aguillard, 482 U.S. 578, 586-88 (1987) (interpreting statutory text and public comment to find an illegitimate purpose for a statute requiring instruction in creationism to accompany evolution teaching).

168. Stone v. Graham, 449 U.S. 39, 42 (1980) (per curiam) (concluding no secular purpose in requiring posting the Ten Commandments on school walls); Sch. Dist. of Abington Twp. v. Schempp, 374 U.S. 203, 223-24 (1963) (finding religious purpose in requiring Bible readings in public schools).

169. See McCreary, 545 U.S. at 863.

170. Id. at 864 .

171. 449 U.S. at 42.

172. Id. at 41 .

173. 374 U.S. at $277-78$

174. 482 U.S. 578, 582, 585-93 (1986).

175. Id. at $586-87$.

176. Id. at 594 . 
permitted instruction in all theories of human origins without making the teaching of one theory contingent upon teaching another. ${ }^{177}$

The Court was equally unconvinced by the government's purported secular purpose in McCreary, which changed each time the government changed its Ten Commandments display. ${ }^{178}$ For the purpose of showing the Ten Commandments as a "creed of ethics" and "good rules to live by," the government's initial display included only the Ten Commandments. ${ }^{179}$ As the litigation progressed, the government added another display containing religious passages to show the Ten Commandments as the "precedent legal code"180 and later added secular historical documents to show the Ten Commandments as "the foundation of American law." 181 Notwithstanding the purported secular purpose, the Court construed the counties' actions as "reaching for any way to keep the religious documents on the walls of the courthouses" ${ }^{\text {"182 }}$ and concluded that the government acted with a predominately religious objective. ${ }^{183}$

These cases demonstrate that when the government's secular purpose is a sham or secondary to a religious purpose, the Court has not hesitated to find the purported purpose illegal, even after giving legislative deference its due consideration. Therefore, courts should not allow legislative deference to impede their discerning review of the proffered legislative purpose for land dispositions. ${ }^{184}$

\footnotetext{
177. Id. at 588-89.

178. See McCreary Cnty. v. ACLU of Ky., 545 U.S. 844, 869-73 (2005).

179. Id. at 851 .

180. Id. at 853 .

181. Id. at $856-57$.

182. Id. at 873 .

183. Id. at 881 .

184. See Salazar v. Buono, 130 S. Ct. 1803, 1840 (2010) (Stevens, J., dissenting) (“Furthermore, in the Establishment Clause context, we do not accord any special deference to the legislature on account of its generic advantages as a policymaking body, and the purpose test is not 'satisfied so long as any secular purpose for the government action is apparent."' (quoting McCreary, 545 U.S. at 865 n.13)).
} 


\section{B. Purpose of Land Disposition}

\section{Maintaining Memorials and Commemorative Objects}

\section{a. Lack of Logical Connection and Universality}

One secular purpose governments have asserted as a basis for selling religious objects and the land underneath them to private parties is the preservation of memorials or commemorative objects. These governmental units argue that the religious object serves a secular purpose by memorializing or commemorating important events, and the object and land beneath must be transferred or sold to preserve them from Establishment Clause challenges. ${ }^{185}$

The problem with this argument is that the symbol being used has no unique logical or historical connection to the purported secular purpose. In the specific case of a cross, it is unnecessary to use a cross as a memorial because "the cross is 'not a generic symbol of death.",186 Contrary to Justice Alito's invoking the imagery of "white crosses, row on row, that marked the final resting places of so many American soldiers who fell in [World War I]" ${ }^{187}$ to suggest the symbolism of the cross as a memorial, historians have found that the cross is not uniquely used to memorialize veterans in the United States. ${ }^{188}$ Moreover, one single cross does not honor individual veterans-a cross for each veteran $^{189}$ does. ${ }^{190}$ The crosses among the fields of poppies, alluded to

185. Governments frequently advance the provision of a war memorial as a justification for permanent displays of religious objects, particularly crosses. E.g., Separation of Church \& State Comm. v. City of Eugene, 93 F.3d 617, 619 (9th Cir. 1996) (per curiam); see also Gonzales v. N. Twp., 4 F.3d 1412, 1414 (7th Cir. 1993); Jewish War Veterans of the U.S. v. United States, 695 F. Supp. 3, 5-6 (D.D.C. 1988); Greater Hous. Chapter of ACLU v. Eckels, 589 F. Supp. 222, 222-23 (S.D. Tex. 1984).

186. Trunk v. City of San Diego, 629 F.3d 1099, 1112 (9th Cir. 2011) (quoting Am. Atheists v. Duncan, 616 F.3d 1145, 1161 (10th Cir.), amended and superseded on reh'g on other grounds sub nom. Am. Atheists v. Davenport, 637 F.3d 1095 (10th Cir. 2010) (en banc), cert. denied sub nom. Utah Highway Patrol Ass'n v. Am. Atheists, Inc., 132 S. Ct. 12 (2011)), cert. denied sub nom. Mount Soledad Mem’l Ass'n v. Trunk, 132 S. Ct. 2535 (2012).

187. Buono, 130 S. Ct. at 1822 (Alito, J., concurring).

188. Trunk, 629 F.3d at 1112. Similarly, the Star of David is not a prevalent symbol for remembering the dead. Eckels, 589 F. Supp. at 227.

189. The federal government recognizes service members by customizing individual headstones to honor each person's faith. See Headstones and Niche Covers, ARLingtON NAT'L CEMETERY, http://www.arlingtoncemetery.mil/FuneralInformation/OrderHeadstone.aspx (last visited Oct. 8, 2012) ("The order for the headstone or niche cover will include the appropriate inscription and choice of emblem of belief.”). Currently, there are fifty-one emblems, representing a range of faiths, that can be carved into individual headstones at Arlington National Cemetery, including symbols for 
by Justice Alito, were used as individual grave makers, instead of as a "universal monument to the war dead." famous poem In Flanders Fields, ${ }^{192}$ not the cross, became the universal symbol $^{193}$ in the United States ${ }^{194}$ and abroad ${ }^{195}$ for the foreign wars. ${ }^{196}$

atheists and Wiccans. See id. (follow "Headstone/Niche Emblems" heading; then follow "Printable List” hyperlink).

Displaying a cross on an individual headstone does not pose Establishment Clause concerns because it is private speech, elected by the individual. See generally Pleasant Grove City v. Summum, 555 U.S. 460, 467-74 (2009) (discussing differences between private and government speech).

190. Buono, 130 S. Ct. at 1836 n.8 (Stevens, J., dissenting).

191. Trunk, 629 F.3d at 1113.

192. I thank Professor Bruce Ledewitz for reminding me of the Great War poem, which reads as follows:

In Flanders fields the poppies blow

Between the crosses, row on row,

That mark our place; and in the sky

The larks, still bravely singing, fly

Scarce heard amid the guns below.

We are the Dead. Short days ago

We lived, felt dawn, saw sunset glow,

Loved and were loved, and now we lie

In Flanders fields.

Take up our quarrel with the foe:

To you from failing hands we throw

The torch; be yours to hold it high.

If ye break faith with us who die

We shall not sleep, though poppies grow

In Flanders fields.

JoHn MCCRAE, In FLANDERS FIELDS AND Other POEMS 3 (1919).

193. An article in the military press explains:

Among the rows in the gardens of stone, life and resurrection spring forth in the form of the red-flowered corn poppy, a common plant in Europe. Canadian surgeon and soldier, Lt. Col. John McCrae wrote the poem "In Flanders Fields” May 3, 1915, after witnessing the death of his friend, Lt. Alexis Helmer.

In tribute to the opening lines of McCrae's poem, Moina Michael vowed in her 1915 poem "We Shall Keep the Faith" to always wear a red poppy as a symbol of remembrance for those who served in the war. Thus the plant became a symbol for the dead World War I soldiers.

Army Capt. Dayna Rowden, Little Red Flowers and Remembering Veterans, U.S. DEP'T DEFENSE (Nov. 11, 2009), http://www.defense.gov/news/newsarticle.aspx?id=56634.

194. The U.S. Department of Defense has featured several articles on its website that recognize the long established symbolism of the poppy. See, e.g., Jim Garamone, Veterans Day Honors Service, Sacrifice, U.S. DEP'T DEFENSE (Nov. 9, 2011), http://www.defense.gov /news/newsarticle.aspx?id=66017 ("Until the 1960s, veterans groups used the red poppy as the symbol of Veterans Day. In Great Britain, it still is.”); Rowden, supra note 193 ("Veterans groups in England, New Zealand, Australia, Canada and the United States have adopted the red poppy as not only a symbol of remembrance of the sacrifice of veterans who have died but of the continued sacrifice that veterans make in service to their countries.”); Erin Wittkop, Memorial Day 2011: 
Like the cross, the Ten Commandments have been advanced as a commemoration of civic responsibility ${ }^{197}$ and similarly lack a connection with this purported secular purpose. In Mercier, for example, the Ten Commandments monument and the land underlying it were sold to preserve the monument as a commemoration of the volunteerism of high school students who filled sandbags during a flood. ${ }^{198}$ But there is no "rational connection" between the Ten Commandments and either the volunteer efforts of high school students or the original purpose of the monument. ${ }^{199}$ The monument was originally conceived to combat juvenile delinquency by providing a code of conduct for troubled youths and as a commercial venture by Cecile B. DeMille to promote his movie

Memorial Day Traditions Live On, U.S. DEP’T DEFENSE, http:/www.defense.gov/home/ features/2011/0511_memorialday/memorialintro.aspx (last visited Sep. 30, 2012) ("Many Americans mark Memorial Day by decorating gravesites with flowers and flags, attending local parades and donning red poppies of remembrance.”).

195. In Canada, the Department of Veterans Affairs promotes the poppy as its symbol to honor veterans:

The red poppy is a symbol of remembrance. During the First World War, the poppy was the only flower that could grow in the ruined fields of France and Belgium. It self-seeded and so could continue growing year after year. Sometimes it was the only spot of colour the soldiers saw as the trees and grass were replaced by the shattered trunks and mud of war. We wear poppies on November 11th to publicly show our respect for and memory of the Canadian men and women who served and died for peace and freedom all over the world.

Veterans' Week 2011 Teacher Guide: Remembrance Symbols Fact Sheets: Poppy, VETERANS AFF. CAN., http://www.veterans.gc.ca/eng/teach_resources/vw11-tguide/bookmarks/poppies (last visited Sep. 30, 2012). As the British Embassy explains, Britain has similarly adopted the poppy symbol. See Holidays and Traditions, UK IN THE USA, http://ukinusa.fco.gov.uk/en/about-us/faqs/holidaystraditions/remembrance-day (last visited Sep. 30, 2012) ("The red poppies represent the poppies that grew in the cornfields of Flanders where many thousands of soldiers lost their lives in the First World War. Wearing a poppy-the symbol of remembrance-remains a small yet significant gesture which helps British people to remember the price of freedom.”).

196. Trunk, 629 F.3d at 1113. Perhaps the poppy was widely used as a symbol of the war because its bright color was a reminder of the spilled blood and its self-seeding represented regeneration and resilience. See Veterans' Week 2011 Teacher Guide, supra note 195; The Red Poppy, N.Z. History ONLINE, http://www.nzhistory.net.nz/war/anzac-day/poppies (last visited Sep. 30, 2012) ("McCrae was a Canadian medical officer who, in May 1915, had conducted the funeral service of a friend, Lieutenant Alexis Helmer, who died in the Second Battle of Ypres (Ieper). Distressed at the death and suffering around him, McCrae scribbled the verse in his notebook. In a cemetery nearby, red poppies blew gently in the breeze-a symbol of regeneration and growth in a landscape of blood and destruction.”).

197. See Mercier v. Fraternal Order of Eagles, 395 F.3d 693, 704-05 (7th Cir. 2005).

198. Id. at 696-97.

199. Mercier v. La Crosse, 305 F. Supp. 2d 999, 1008 (W.D. Wis. 2004), rev'd sub nom. Mercier v. Fraternal Order of Eagles, 395 F.3d 693 (7th Cir. 2005). 
The Ten Commandments. ${ }^{200}$ Moreover, because approximately 5,500 copies of the Ten Commandments monuments were distributed to various cities throughout the country, ${ }^{201}$ there is no special connection between the monument and the identity of any particular city. Also, the city's legislative purpose in preserving the Ten Commandments monument is suspect because the city accepted the monument long before the flood happened. ${ }^{202}$ "Thus, at most, the dedication was an afterthought. There is no evidence to suggest that the city would have declined to install the monument if the volunteers had not worked as tirelessly as they did."203

\section{b. Expressing Sectarian Preference}

Religious symbols inadequately serve as a memorial or commemoration of secular events not only because they lack universality as a symbol for the purported purpose but also because they have potential to exclude others. First, the religious nature of the symbols preserved through the land dispositions can make nonbelievers feel like outsiders. Courts have acknowledged, for example, the Ten Commandments as being primarily religious. Even in Van Orden, which upheld the Ten Commandments display, the plurality conceded that "[o]f course, the Ten Commandments are religious - they were so viewed at their inception and so remain."204 Justice Breyer, who provided the deciding fifth vote in Van Orden, agreed that "the Commandments' text undeniably has a religious message, invoking, indeed emphasizing, the Deity."205

Second, displays like the cross or Ten Commandments, in addition to having religious significance, express a sectarian preference. The Ten Commandments, for instance, favor Judaism, Christianity, ${ }^{206}$ and

\footnotetext{
200. See Books v. City of Elkhart, 235 F.3d 292, 294-95 (7th Cir. 2000).

201. Chambers v. City of Frederick, 373 F. Supp. 2d 567, 569 (D. Md. 2005).

202. See Mercier, 305 F. Supp. 2d at 1008.

203. Id.; see also Books, 235 F.3d at 304 (rejecting "avowed secular purpose of recognizing the historical and cultural significance of the Ten Commandments, issued on the eve of litigation”).

204. Van Orden v. Perry, 545 U.S. 677, 690 (2005) (plurality opinion).

205. Id. at 700-01 (Breyer, J., concurring).

206. See Douglas Laycock, Government-Sponsored Religious Displays: Transparent Rationalizations and Expedient Post-Modernism, 61 CASE W. RES. L. REV. 1211, 1219 (2011) (explaining that the Ten Commandments monument "explicitly presents the Commandments as Christians and Jews have always understood them—as the direct Word of God").
} 
Islam, ${ }^{207}$ for which the Ten Commandments is a sacred text. ${ }^{208}$ Thus, choosing one version of the Ten Commandments or of a cross necessarily implicates religious endorsement because it represents approval of one sect over another. ${ }^{209}$ For example, in Glassroth $v$. Moore, Chief Justice Moore of the Alabama Supreme Court erected a monument of the Ten Commandments in the rotunda of the Alabama State Judicial Building. ${ }^{210}$ The Ten Commandments displayed by Chief Justice Moore was a Christian version, which partly contradicts the Hebrew version. ${ }^{211}$

Similarly, the Latin cross has been described as "one of the most sacred of religious symbols,"212 "an especially potent sectarian symbol,"213 "the principal symbol of Christianity around the world,",214 “a symbol of a particular religion, that of Christianity," 215 and a "symbol of particular denominations within Christianity."216 The cross not only

207. See McCreary Cnty. v. ACLU of Ky., 545 U.S. 844, 894 (2005) (Scalia, J., dissenting) (noting that Islam recognizes the Ten Commandments).

208. See Van Orden, 545 U.S. at 716 (Stevens, J., dissenting) (quoting Stone v. Graham, 449 U.S. 39, 41 (1980) (holding that the Ten Commandments are a sacred text to the Jewish and Christian faiths)).

209. See Glassroth v. Moore, 335 F.3d 1282, 1299 n.3 (11th Cir. 2003) (“[C]hoosing which version of the Ten Commandments to display can have religious endorsement implications under the Establishment Clause.”).

210. Id. at 1284 .

211. Id. at 1299 n.3.

212. Capitol Square Review \& Advisory Bd. v. Pinette, 515 U.S. 753, 771 (1995) (Thomas, J., concurring).

213. Id. at 776 (O’Connor, J., concurring).

214. Id. at 792 (Souter, J., concurring).

215. Id. at 798 n.3 (Stevens, J., dissenting); see also W. Va. State Bd. of Educ. v. Barnette, 319 U.S. 624, 632 (1943) (“[T]he church speaks through the Cross ....”); Gonzales v. N. Twp., 4 F.3d 1412, 1417 (7th Cir. 1993) ("But we are masters of the obvious, and we know that the crucifix is a Christian symbol. We reached a similar conclusion about the Latin cross, acknowledging that it is 'an unmistakable symbol of Christianity as practiced in this country today.'” (quoting Harris v. City of Zion, 927 F.2d 1401, 1403 (7th Cir. 1991))); ACLU of Ill. v. City of St. Charles, 794 F.2d 265, 271 (7th Cir. 1986) ("[The Latin cross] is, indeed, the principal symbol of Christianity as practiced in this country today.”); ACLU of Ga. v. Rabun Cnty. Chamber of Commerce, 698 F.2d 1098, 1103 (11th Cir. 1982) ("[T]he [L]atin cross is a universally recognized symbol of Christianity.”); Hewitt v. Joyner, 705 F. Supp. 1443, 1449 (C.D. Cal. 1989) (“[T]he Latin cross epitomize[s] Christian faith. In fact, the Latin Cross is the pre-eminent symbol of many Christian religions and clearly represents the key Christian concept of the Crucifixion and Resurrection of Christ."), rev'd, 940 F.2d 1561 (9th Cir. 1991); Mendelson v. City of St. Cloud, 719 F. Supp. 1065, 1069 (M.D. Fla. 1989) ("The Latin cross is unmistakably a universal symbol of Christianity.”); Jewish War Veterans of the U.S. v. United States, 695 F. Supp. 3, 13 (D.D.C. 1988) ("[T]he Latin cross ... is a readily identifiable symbol of Christianity.”); Greater Hous. Chapter of ACLU v. Eckels, 589 F. Supp. 222, 234 (S.D. Tex. 1984) ("That the cross ... [is] the primary symbol[] for Christianity . . . is beyond question.”).

216. Pinette, 515 U.S. at 798 n.3 (Stevens, J., dissenting). 
excludes non-Christians, but also other sects within Christianity $^{217}$ that do not recognize the cross as their religious symbol. ${ }^{218}$

The litigation brought by the Jewish War Veterans is an example of how the cross fails to represent all war veterans and how it can be perceived to dishonor those veterans whose faiths the cross does not represent. ${ }^{219}$ In Trunk, after the federal government seized the memorial through eminent domain, the Jewish War Veterans-“"the oldest active national veterans' service in America"-challenged the cross display. ${ }^{220}$ One veteran expressed:

I don't know if it is a Christian monument, but it does not speak for me. I was under Hitler and in a concentration camp and a cross does not represent me. The Cross does not represent all veterans and I do not know how they can say it represents all veterans. I do not think a cross can represent Jewish veterans. ${ }^{221}$

\section{c. Secular Purpose as a Derivative of Religious Meaning}

While maintaining a memorial is a legitimate secular interest, maintaining a memorial through the use of a religious symbol is not. Any purported secular purpose for the religious object, like a cross memorializing self-sacrifice, cannot be divorced from the object's

217. See id. (“[T] he Latin cross is identifiable as a symbol of a particular religion, that of Christianity; and, further, as a symbol of particular denominations within Christianity.”).

Some Justices do not view the Latin cross as religious. See Steven Goldberg, The Coming Demise of the Crucifix, 12 RutGers J.L. \& RELIGION 277, 278 (2011). Professor Steven Goldberg explains that an unadorned cross may not be seen as religious symbol to the Catholic Justices because Catholics generally associate the crucifix as their religious symbol, rather than a plain cross. Id.

Empirical research reveals that in "religious freedom decisions, the single most prominent, salient, and consistent influence on judicial decision making was religion-religion in terms of affiliation of the claimant, the background of the judge, and the demographics of the community." Gregory C. Sisk, Michael Heise \& Andrew P. Morriss, Searching for the Soul of Judicial Decisionmaking: An Empirical Study of Religious Freedom Decisions, 65 OHIO ST. L.J. 491, 614 (2004); see also Scott C. Idleman, The Concealment of Religious Values in Judicial Decisionmaking, 91 VA. L. REV. 515, 521-23 (2005) (showing the effect of judicial religious affiliations on various types of cases).

218. ACLU, Myths And ReAlities: Gravestones AND MARKERS ARE NOT IN DANGER, (July 26, 2006), http://www.aclu.org/files/images/asset_upload_file399_26244.pdf ("Even within the Christian faith, many sects do not recognize the Latin cross as their preferred religious symbol.”).

219. See Trunk v. City of San Diego, 629 F.3d 1099, 1105 (9th Cir. 2011), cert. denied sub nom. Mount Soledad Mem’l Ass’n v. Trunk, 132 S. Ct. 2535 (2012).

220. Id.

221. Id. at 1125 . 
religious meaning. ${ }^{222}$ For example, the cross symbolizes the death of Jesus Christ, ${ }^{223}$ and any secondary meaning for the cross is derivative of that original symbolism. ${ }^{224}$ In Buono, Justice Kennedy makes a contrary argument by suggesting that the meaning of the cross is changed when Congress adopts it as a memorial. ${ }^{225}$ This argument is perplexing because it implies that the message or meaning of an object that has stood for seventy years is subject to change by sudden legislative acts. Since 1935, the cross has inspired Easter Sunrise services, but never Armistice Day or Veterans Day services until the litigation commenced. ${ }^{226}$

Likewise, Congress cannot erase the cross's primary meaning or the history of religious activities that have taken place in Trunk. The cross in Trunk was dedicated on Easter Sunday in a Christian religious ceremony ${ }^{227}$ "as a reminder of God's promise to man of everlasting life and of those persons who gave their lives for our freedom."228 Mount Soledad was selected because it was "worthy to be a setting for the symbol of Christianity."229 The cross stood by itself for much of the time since its installation. $^{230}$ Only in the late 1990s, in response to controversy over the cross, were a plaque and other displays that honor individual veterans added to signify the site as a war memorial. ${ }^{231}$ Also, visitors have held annual Easter services at the site during much of the cross's history, but Veterans' memorial services at the site began only in the late 1990 s. $^{232}$

\footnotetext{
222. See Libin v. Town of Greenwich, 625 F. Supp. 393, 399 n.4 (D. Conn. 1985) (“[T]he cross is primarily a religious symbol. Any secondary meaning as a symbol of peace appears to be derived from the teachings of Christ as set forth in the tenets of the Christian religions to which the cross is sacred.”).

223. See Am. Atheists v. Duncan, 616 F.3d 1145, 1161 (10th Cir.) (describing the cross as a "Christian symbol of death"), amended and superseded on reh'g on other grounds sub nom. Am. Atheists, Inc. v. Davenport, 637 F.3d 1095 (10th Cir. 2010) (en banc), cert. denied sub nom. Utah Highway Patrol Ass'n v. Am. Atheists, 132 S. Ct. 12 (2011).

224. See Laycock, supra note 206, at 1239 (arguing that the cross's "secondary meanings would make no sense without the primary meaning.").

225. See Christopher Lund, Salazar v. Buono and the Future of the Establishment Clause, 105 NW. U. L. REV. 1387, 1396 (2011).

226. Salazar v. Buono, 130 S. Ct. 1803, 1838 n.9 (2010) (Stevens, J., dissenting).

227. Murphy v. Bilbray, 782 F. Supp. 1420, 1437 (S.D. Cal. 1991).

228. Trunk v. City of San Diego, 629 F.3d 1099, 1101 (9th Cir. 2011) (internal quotation marks omitted), cert. denied sub nom. Mount Soledad Mem'l Ass’n v. Trunk, 132 S. Ct. 2535 (2012).

229. Id.

230. Id. at 1103.

231. Id.

232. Id.
} 
Similarly, the secular purposes asserted for the Ten Commandments, ${ }^{233}$ whether based on the text's supposed historic value or influence as a moral code, cannot exist without reliance on the primary religious meaning. "To say that the Commandments are 'historical' is to repeat the fallacy of Lynch $v$. Donnelly. A miracleGod's appearance on a mountaintop to carve laws in stone-is 'historical' only if it really happened. Whether it really happened is a matter of faith.,234

Finally, the problem with justifying land dispositions to maintain religious symbols as commemorative objects is that "[i]t borders on the preposterous to argue that the government can avoid an [E]stablishment [C]lause violation by 'dedicating' a religious object to a nonreligious group.”235 If this argument were true, governmental bodies could erect unlimited permanent religious symbols - maybe even churches-on any public property as long as they could dedicate them to secular groups. ${ }^{236}$

In sum, the use of religious symbols for a memorial is unnecessary, and, consequently, religious symbols should be removed without carving up public land. As history has shown, a government can easily provide a memorial without "embedding its actions in any particular religious narrative.”237 In fact, many memorials, such as the Vietnam Veterans Memorial, honor the fallen service members without use of religious symbols. ${ }^{238}$ As the Ninth Circuit pointed out, "there are countless ways that we can and should honor [veterans], but without the imprimatur of state-endorsed religion." ${ }^{239}$

\section{Avoiding Showing Disrespect to Religion}

Another possible secular purpose governments use to justify sales and transfers of religious objects and land under them is that removing a

233. Some theologians believe that the Ten Commandments cannot operate as a secular text because the Commandments "teach us how to worship God, not how to build democracy." GRIFFIN, supra note 137, at 455 (quoting theologians Stanley M. Hauerwas and William H. Willimon).

234. Laycock, supra note 206, at 1220.

235. Mercier v. City of La Crosse, 305 F. Supp. 2d 999, 1008 (W.D. Wis. 2004), rev'd sub nom. Mercier v. Fraternal Order of Eagles, 395 F.3d 693 (7th Cir. 2005).

236. Id.

237. Andrew Koppelman, No Expressly Religious Orthodoxy: A Response to Steven D. Smith, 78 CHI.-KENT L. REV. 729, 734 (2003).

238. See Greater Hous. Chapter of ACLU v. Eckels, 589 F. Supp. 222, 234 (S.D. Tex. 1984).

239. Trunk v. City of San Diego, 629 F.3d 1099, 1102 (9th Cir. 2011), cert. denied sub nom. Mount Soledad Mem’l Ass’n v. Trunk, 132 S. Ct. 2535 (2012). 
monument or symbol would risk showing disrespect toward religion. ${ }^{240}$ The argument concludes that because removing a religious object will show hostility toward religion, the best recourse is to transfer or sell the religious object and the land beneath it. ${ }^{241}$

First, the government's concern for the appearance of disrespect that might result from an object's removal underscores the object's religious significance. Disrespect would be perceived, if at all, only by those who hold religious reverence for the object. The concern over causing disrespect thereby undermines the government's purported secular interest in disposing of public land. Even if a religious object can have dual religious and secular meanings, as Justice Breyer espoused in Van Orden, ${ }^{242}$ the concern for causing religious disrespect brings religion to the forefront of the government's actions and renders any purported secular purpose secondary to a religious one. ${ }^{243}$

Second, if the government were concerned about the appearance of governmental disrespect for religion when it removes an object by its own hands, it could simply sell the object-not the land-and allow private hands to remove it. Under new ownership, the appearance of governmental disrespect dissipates because, presumably, the public possesses a common understanding of private ownership and that private owners may do what they wish with the property. For example in Mercier, removal of the Ten Commandments monument would not have risked showing disrespect toward religion because an Episcopal church

240. See Salazar v. Buono, 130 S. Ct. 1803, 1822-23 (Alito, J., concurring) ("[T]his removal would have been viewed by many as a sign of disrespect for the brave soldiers whom the cross was meant to honor. The demolition of this venerable if unsophisticated, monument would also have been interpreted by some as an arresting symbol of a Government that is not neutral but hostile on matters of religion ....”); see also id. at 1817 (plurality opinion) ("The ... [Government] could not . . . remove the cross without conveying disrespect for those the cross was seen as honoring.").

Ironically, after the Court's decision in Buono, the cross was stolen by a veteran who explained, in an anonymous letter, that he removed it to defend the Constitution. Anonymous Letter Explaining Cross Theft Sent to Desert Dispatch, Desert Dispatch (May 11, 2010, 5:27 PM), http://www.desertdispatch.com/news/explaining-8465-anonymous-letter.html. The cross was anonymously replaced within a week but then promptly removed by the National Park Service because the installation was illegal. See Replica Cross Mysteriously Appears in Mojave, MSNBC.COM (May 20, 2010, 9:04 PM), http://www.msnbc.msn.com/id/37261550.

241. See infra Part V.B. for additional discussion concerning whether the removal of religious symbols has the effect of inhibiting or disapproving of religion as prohibited by the second prong of the Lemon and endorsement tests.

242. See Van Orden v. Perry, 545 U.S. 677, 701 (2005) (Breyer, J., concurring) (discussing the display's multiple meanings).

243. It could be argued that the inverse is true, that by not allowing the government to consider religious offense, the government is inhibiting or disapproving of religion in violation of the Establishment Clause. I address these arguments in Part V.B. 
and the Eagles, the original donor, had offered to move the monument to another location visible to the public. ${ }^{244}$ Since the Eagles' headquarters was located directly across from the park, ${ }^{245}$ removing the monument to the Eagles' property would not have diminished the visibility of the monument. Rather than accepting these offers that would have easily resolved any Establishment Clause violation, the city resorted to changing the character of public land through privatization to keep the monument in its original location, ${ }^{246}$ leading one judge to conclude that the city "show[ed] a stubborn refusal to separate itself from the display of a purely religious monument." 247 The city's rejection of all three offers $^{248}$ undermines its purported need to sell the monument and underlying land to avoid the appearance of disrespect toward religion.

Further, the government's justification, premised on showing respect for religion, seems disingenuous not only because there is a readily available alternative, but also because its own actions taken to retain religious objects may appear disrespectful to other religions. Governmental efforts to preserve a religious symbol on public land are disrespectful to nonadherents as well as devout believers. One way the government can appear disrespectful toward religion is by denying other religious groups equal access to erect symbols of their faith on public land. ${ }^{249}$ In Buono, the government denied a request to build a Buddhist stupa near the cross ${ }^{250}$ but made "herculean efforts" to save the existing cross from being removed. ${ }^{251}$ The federal government went to great lengths to preserve the cross by passing four successive laws, some of which within months of the district court's decisions. ${ }^{252}$ The government's rejection of the stupa causes as much disrespect toward religion as the cross's removal might. Granted, it would be more

\footnotetext{
244. Mercier v. Fraternal Order of Eagles, 395 F.3d 693, 696 (7th Cir. 2005).

245. Id. at 695 .

246. Id. at 696 .

247. Id. at 706 (Bauer, J., dissenting).

248. Id. at 696 .

249. This Article does not argue that allowing other groups to install religious symbols would mitigate the Establishment Clause violation, but merely that rejecting other religious symbols would open the government to greater Establishment Clause problems when it insists on selling the religious object and land underlying it.

250. Buono IV, 527 F.3d 758, 769 (9th Cir. 2008), rev'd and remanded sub nom. Salazar v. Buono, 130 S. Ct. 1803 (2010).

251. Buono III, 364 F. Supp. 2d 1175, 1182 (C.D. Cal. 2005), aff'd sub nom. Buono IV, 527 F.3d 758 (9th Cir. 2008), rev'd and remanded sub nom. Salazar v. Buono, 130 S. Ct. 1803 (2010).

252. See Buono IV, 527 F.3d at 769-71 (discussing the laws passed by Congress designed to preserve the cross).
} 
obvious when a religious object resting on public land is removed than when the government silently denies a request to erect a new religious object. But an unsuccessful donor will feel the sting of a perceived religious rebuff when the religious object is not erected just as much as a successful donor would when the object is removed.

Another way government preservation of religious symbols through land dispositions can be disrespectful to religion is through secularizing the symbol. Government secularization of religious objects may harm religion by "diminish[ing] respect for religion"253 because the government must disclaim or disassociate the religious significance of the object to assert a secular purpose for the object. ${ }^{254}$ As Professor Stanley Fish points out, "It is one of the ironies of the sequence of cases dealing with religious symbols on public land that those who argue for their lawful presence must first deny them the significance that provokes the desire to put them there in the first place.”255 As Professor Steven Goldberg observes,

People of faith who pushed to have the cross accepted as a war memorial made the same mistake that was made when crèches, menorahs, and Santa Claus began cavorting on courthouse lawns, and when the Ten Commandments became a blank slate rather than a

253. See Koppelman, supra note 237, at 735 (describing the theory that religion is harmed by government support).

254. Professor William Marshall explains:

[T] he possibility that government practices may through time become "secularized" further compounds the issue. Many persons who would question the result in Lynch, for example, have apparently accepted the national celebration of Christmas as permissible. For them, apparently, Christmas is primarily a secular event while the nativity scene is primarily religious. But who decides what is secular and what is religious? Strong Christians are likely to view the holiday as having religious content equally as strong as, if not stronger than, a créche. To them description of the holiday as a folk event is certainly as demeaning of their religious principles as a similar depiction is of the créche. Similarly, Christmas is not a secular occurrence to many non-Christians, and public celebration of the holiday is as offensive and alienating as the display of a créche. Perhaps a greater segment of the population might find the créche to be more religious than the holiday; but even so, should the majority rule? In any event, how should the threshold of "secularization" be determined? Whose perspective (and perception) should govern?

Marshall, supra note 19, at 534-35 (footnotes omitted).

255. Stanley Fish, When is a Cross a Cross?, N.Y. Times Opinionator (May 3, 2010, 9:00 PM), http://opinionator.blog.nytimes.com/2010/05/03/when-is-a-cross-a-cross/; see also Ian Bartrum, Salazar v. Buono, Sacred Symbolism and the Secular State, 104 Nw. U. L. REV. 1653, 1662 (2010) (discussing Fish's article); Goldberg, supra note 217, at 278 (arguing that the secularization of religious symbols damages their religious significance). 
biblical text. They were promoting a bleached faith in which real religion is the loser. ${ }^{256}$

The opposition to secularizing religious symbols, and the resulting harm, are evident in a number of cases. In Donnelly $v$. Lynch, because the crèche $\mathrm{e}^{257}$ is part of religious worship, an ordained minister "expressed dismay that the City had demeaned this Christian religious symbol by setting it in the midst of other, non-religious symbols." 258 In Glassroth $v$. Moore, when a request was made to place a monument displaying a historic speech near the Ten Commandments monument, Chief Justice Moore insisted that no other monument share the same space because he believed that " $[\mathrm{t}] \mathrm{he}$ placement of a speech of any man alongside the revealed law of God would tend in consequence to diminish the very purpose of the Ten Commandments monument." ${ }^{259}$ In Greater Houston Chapter of the American Civil Liberties Union v. Eckels, the Star of David that was used to memorialize veterans was also offensive to adherents. $^{260}$ For one rabbi, the Star of David evoked memories of the Holocaust and Nazi denigration of Jews. ${ }^{261}$ One reverend objected to the Star of David and crosses as memorials because they "'water down' or adulterate the very precise religions of Christianity and Judaism.,"262

This discussion is not meant to suggest that government objectives should yield to a heckler's veto or the "tyranny of the squeamish" created by thin-skinned individuals. ${ }^{263}$ To the contrary, religious disparagement caused by the secularization of religious objects harms the very community that the government intended to avoid offending. ${ }^{264}$ Moreover, the perception of religious disrespect is not the result of an

256. Goldberg, supra note 217, at 278 (footnote omitted); see also Capitol Square Review \& Advisory Bd. v. Pinette, 515 U.S. 753, 812 n.19 (1995) (Stevens, J., dissenting) ("There is always a risk that such symbols will offend nonmembers of the faith being advertised as well as adherents who consider the particular advertisement disrespectful.” (quoting Cnty. of Allegheny v. ACLU Greater Pittsburgh Chapter, 492 U.S. 573, 650-51 (1989) (Stevens, J., concurring in part and dissenting in part))).

257. A crèche is a representation of the Nativity scene.

258. 525 F. Supp. 1150, 1160 (D.R.I. 1981), aff'd, 691 F.2d 1029 (1st Cir. 1982), rev'd, 465 U.S. 668 (1984).

259. 335 F.3d 1282, 1284 (11th Cir. 2003) (alteration in original) (quoting Glassroth v. Moore, 229 F. Supp. 2d 1290, 1297 (M.D. Ala. 2002)).

260. 589 F. Supp. 222, 226 (S.D. Tex. 1984).

261. Id.

262. Id. at 227.

263. See CHristopher L. EISGRUBER \& LAWRENCE G. SAGER, RELIGIOUS FreEdOM AND THE CONSTITUTION 127 (2007).

264. Id. 
obscure or unconventional interpretation of the religious symbol's meaning. Rather, it results from the understanding of "competent practitioner[s] in the relevant linguistic community" who are familiar with the social meaning of the religious symbol. ${ }^{265}$ The government, therefore, should be cognizant of the unintended consequences that undermine the very objective it seeks to achieve.

Thus, if disrespect to religion is a consideration, then any perceived disrespect resulting from removal of religious objects must be balanced against the disrespect that would occur through the maintenance of religious objects. And if accommodation is the appropriate policy to further the ideals of the Establishment Clause, as the Buono plurality suggests, ${ }^{266}$ then removing the religious object best accommodates the concerns of religious adherents and nonbelievers. Because there is equal risk of offending religious adherents by removing the religious symbol as well as retaining it and greater risk of offending nonadherents by retaining the object, if showing religious disrespect were a factor, it should tilt in favor of removing the object. The appearance of disrespect to religion can easily be mitigated by allowing private parties to remove the object, ${ }^{267}$ whereas the disrespect arising from secularization of religious objects can only be prevented by not installing religious objects.

\section{Avoiding Establishment Clause Violations}

A final secular purpose governments advance to justify selling religious objects and the public land they rest on is the avoidance of Establishment Clause violations. Governmental compliance with the Constitution is unquestionably a legitimate purpose, but this defense suffers from the same problem as using a religious symbol for a memorial or commemoration. Both defenses ignore alternative measures of achieving the purported secular purpose.

265. Id.

266. Salazar v. Buono, 130 S. Ct. 1803, 1819-20 (2010) (plurality opinion) (suggesting that the Establishment Clause "leaves room to accommodate divergent views within a constitutionally permissible framework”).

267. See Summum v. City of Duchesne, 340 F. Supp. 2d 1223, 1228-29 (D. Utah 2004) (noting the removal of the monument would be a sufficient solution), rev'd, 482 F.3d 1263 (10th Cir. 2007), vacated sub nom. Duchesne City v. Summum, 555 U.S. 1210 (2009). 
In Larkin v. Grendel's Den, Inc., the Court found the existence of alternative secular measures relevant in evaluating legislative purpose. ${ }^{268}$ In Larkin, a state statute allowed schools and churches to object to the issuance of liquor licenses ${ }^{269}$ to "protect[] spiritual, cultural, and educational centers from the 'hurly-burly' associated with liquor outlets." ${ }^{270}$ While recognizing the validity of this secular purpose, the Court pointed out that the government's purpose could have been achieved by other means, such as completely banning liquor establishments near churches and schools or providing applicants with a hearing when objections are made. ${ }^{271}$ As the law then existed, it effectively allowed churches veto power over liquor licenses because it failed to provide a standard for determining acceptable objections, and, consequently, it violated the Establishment Clause. ${ }^{272}$

268. 459 U.S. 116, 123-24 (1982) (“[T]hese valid secular objections can readily be accomplished by other means.”); see also Capitol Square Advisory \& Review Bd. v. Pinette, 515 U.S. 753, 793 (1995) (Souter, J., concurring) (reasoning that the government "was required to find its most 'narrowly drawn alternative"” when confronted with an Establishment Clause concern arising out of Ku Klux Klan's application to erect a cross in a public square (quoting Perry Educ. Ass'n v. Perry Local Educators’ Ass'n, 460 U.S. 37, 45 (1983))); Lemon v. Kurtzman, 403 U.S. 602, 659 (1971) (Brennan, J., concurring) ("I conclude that, in using sectarian institutions to further goals in secular education, the three statutes do violence to the principle that 'government may not employ religious means to serve secular interests, however legitimate they may be, at least without the clearest demonstration that nonreligious means will not suffice.”' (quoting Sch. Dist. of Abington Twp. v. Schempp, 374 U.S. 203, 265 (1963) (Brennan, J., concurring))); Walz v. Tax Comm'n of N.Y., 397 U.S. 664, 680 (1970) (Brennan, J., concurring) ("What the Framers meant to foreclose, and what our decisions under the Establishment Clause have forbidden, are those involvements of religious with secular institutions which (a) serve the essentially religious activities of religious institutions; (b) employ the organs of government for essentially religious purposes; or (c) use essentially religious means to serve governmental ends, where secular means would suffice."); McGowan v. Maryland, 366 U.S. 420, 466-67 (1961) (Frankfurter, J., dissenting) (“[I]f a statute furthers both secular and religious ends by means unnecessary to the effectuation of the secular ends alone-where the same secular ends could equally be attained by means which do not have consequences for promotion of religion-the statute cannot stand.”); Susan Hanley Kosse, A Missed Opportunity to Abandon the Reasonable Observer Framework in Sacred Text Cases: McCreary County v. ACLU of Kentucky and Van Orden v. Perry, 4 First AmEND. L. Rev. 139, 173-74 (2006) (discussing the narrowly tailored requirement with respect to sacred texts displayed with an apparent connection to a secular theme). But see Cnty. of Allegheny v. ACLU Greater Pittsburgh Chapter, 492 U.S. 573, 636 (1989) (O’Connor, J., concurring) (rejecting “less religious alternative” analysis).

269. Larkin, 459 U.S. at 117

270. Id. at 123 (alteration in original) (quoting Grendel's Den Inc., v. Goodwin, 495 F. Supp. 761, 766 (D. Mass. 1980)) (internal quotation marks omitted).

271. Id. at 123-24. But see Gallagher v. Crown Kosher Super Mkt. of Mass., 366 U.S. 617, 630 (1961) (rejecting appellant's request to invalidate Sunday closure laws on basis that the government has alternative means to achieve secular purpose).

272. Larkin, 459 U.S. at $125-27$. 
Similarly, just as the government can protect churches from the hurly-burly of liquor establishments without giving them veto power over liquor licenses, the government can comply with the strictures of the Establishment Clause without divesting the public of land beneath the religious object. The most obvious remedy for Establishment Clause violations is simply to remove the religious objects from public landnot to devise complex land sales or transfers to change the character of the land from public to private. It is incumbent upon the government to use "reasonable alternatives that are less religious in nature" to avoid an Establishment Clause violation. ${ }^{273}$ Removing the religious object poses no risk of conveying a religious message. On the other hand, government sales or transfers of the land underlying the religious objects risk perpetuating the Establishment Clause violation because of the extreme measures the government takes to save the religious symbol. Although use of alternative measures is not an independent test of the Establishment Clause, ${ }^{274}$ a government's rejection of less religious alternatives sheds light on the sincerity of its avowed secular purpose and is relevant to whether the sale has the effect of endorsing religion. ${ }^{275}$ When the government has two options to avoid Establishment Clause violations, one being the removal of the religious object and the other being to transfer or sell the land beneath it, a reasonable observer could infer that the government intended to promote religious faith when it decides to sell the underlying public land. ${ }^{276}$

273. Allegheny, 492 U.S. at 618 (Blackmun, J., concurring in part and dissenting in part) (reasoning that where the government has two symbols to convey its secular message, only one of which has religious significance, the government's selection of the one that has religious significance conveys to a reasonable observer that the government intended to advance religious faith). But see id. at 636 (O’Connor, J., concurring) (rejecting "less religious alternative" analysis); Freedom From Religion Found. v. City of Marshfield, 203 F.3d 487, 497 (7th Cir. 2000) (suggesting "that this perceived endorsement of religion can be alleviated without recourse to removal of the statue from Fund-owned property").

274. See Lynch v. Donnelly, 465 U.S. 668, 681 n.7 (1984) (emphasizing that the only question is whether a crèche violated the Establishment Clause).

275. See ACLU of Ga. v. Rabun Cnty. Chamber of Commerce, 698 F.2d 1098, 1111 (11th Cir. 1983) (“[A] government may not 'employ religious means to reach a secular goal unless secular means are wholly unavailing.” (quoting Sch. Dist. of Abington Twp. v. Schempp, 374 U.S. 203, 294 (1963))); Jewish War Veterans of U.S. v. United States, 695 F. Supp. 3, 14 (D.D.C. 1988) ("While federal courts for the most part have stopped short of holding the use of religious tools where secular ones will do unconstitutional per se, it seems fair to say that the needless use of means that are inherently religious makes a message of endorsement likely if not unavoidable.”); Greater Hous. Chapter of ACLU v. Eckels, 589 F. Supp. 222, 234 (S.D. Tex. 1984) ("[T]he use of religious means to achieve secular goals where nonreligious means will suffice is forbidden.”); see also Larkin, 459 U.S. at $123-25$.

276. See Paulson v. Abdelnour, 51 Cal. Rptr. 3d 575, 598 (Cal. Ct. App. 2006) (“[W]here other 
Finally, if merely articulating avoidance of an Establishment Clause violation as a secular purpose were sufficient to uphold land sales or transfers, it would render the Establishment Clause a nullity through circumvention. $^{277}$ In Mercier, the Seventh Circuit disavowed such a stance: "We are not endorsing a non-remedial initiative designed to sell off patches of government land to various religious denominations as a means of circumventing the Establishment Clause. We therefore reject the idea that the sale was a violation of the Establishment Clause simply because the City had other options."278 But indeed, when a court allows a government to sell or transfer land while other options exist, it has provided the means for the government to circumvent the Establishment Clause.

The government speech doctrine, as interpreted in Pleasant Grove City, provides such a vehicle for circumvention. Hypothetically, the government could engage in viewpoint discrimination by selectively accepting permanent monuments and objects for its public spaces while rejecting others. ${ }^{279}$ Then, the government could shield itself from a Free Speech Clause violation by invoking the government speech doctrine. ${ }^{280}$ After accepting the religious object, the government could keep the monument on public land until objections against the display reach the courts. Once a legal challenge is filed, the government could retain the object in the very spot by merely transferring the property. There is nothing to keep the government from repeating these actions for each religious object it wants permanently erected on public land.

Summum v. Duchesne City is one example of a government using a land sale to circumvent the Establishment Clause. ${ }^{281}$ In this case, the city accepted a donation of a stone monolith depicting the Ten

nonsectarian options are available, government has lent its prestige and power through a sectarian choice.”).

277. See Books v. City of Elkhart, 235 F.3d 292, 304 (7th Cir. 2000) ("[A]lthough this court 'will defer to a municipality's sincere articulation of a religious symbol's secular purpose,' we shall not accept a stated purpose that merely seeks to avoid a potential Establishment Clause violation." (quoting Gonzales v. N. Twp., 4 F.3d 1412, 1419 (7th Cir. 1993))).

278. Mercier v. Fraternal Order of Eagles, 395 F.3d 693, 702 (7th Cir. 2005).

279. See Pleasant Grove City v. Summum, 555 U.S. 460, 464 (2010) (finding the city’s decision to accept privately donated monuments is government speech and therefore not subject to the Free Speech Clause).

280. See id.

281. 340 F. Supp. 2d 1223 (D. Utah 2004), rev’d, 482 F.3d 1263 (10th Cir. 2007), vacated, 555 U.S. 1210 (2009). 
Commandments for its public park. ${ }^{282}$ Threatened by litigation, the city transferred the monument and the land underlying it to the Duchesne City Lion's Club. ${ }^{283}$ The only consideration for the land and monument was "the Lion's Club's previous, current and future services to the community."284 Three weeks later, Summum requested a similar plot of land next to the Ten Commandments monolith on which to place a monument of the Seven Aphorisms. ${ }^{285}$ The city denied Summum's request, unequivocally informing Summum that it would not be allowed to erect its own monument until it donated equivalent time and service to the community as the Lion's Club and the family that donated the monolith. ${ }^{286}$ Subsequently, Summum filed a lawsuit alleging violations of its Free Speech rights. ${ }^{287}$ During the litigation, the city nullified the land transfer to the Lion's Club and passed ordinances authorizing the city to sell a parcel of land in the park on which the monument rested to the family who originally donated the monument and to permanently close the park to future private displays. ${ }^{288}$ The city sold the land for fair market value, and, after the sale, the private owner erected a fence and a sign. ${ }^{289}$ The district court upheld the sale as an "adequate" method for the city to disassociate itself from the monument. ${ }^{290}$

As Duchesne City illustrates, allowing the government to sell the land beneath a religious object permits the government to make an endrun around constitutional mandates. The city exercised preferential treatment by allowing the Ten Commandments monument but rejecting the Seven Aphorisms monument. The city then ensured the continued display of the preferred religious monument through the land sale and ensured, by closing the public park entirely to private displays, that no other group be afforded equal access.

Like in Duchesne City, the potential for the government to circumvent the Establishment Clause was present in Buono. There, an individual had requested permission to erect a Buddhist stupa beside an

\footnotetext{
282. Id. 1223-24.

283. Id. at 1224 .

284. Id.

285. Id

286. Id

287. Id.

288. Id. at 1225.

289. Id.

290. Id. at 1230 .
} 
existing cross. ${ }^{291}$ Because the government denied the request on grounds of violating National Park Service regulations, the stupa was never installed. ${ }^{292}$ If the government now, after transferring land to the cross's donor, is permitted to deny a subsequent request for land transfer by the individual interested in erecting a stupa, the government effectively would be permitted to disregard the strictures of the Establishment Clause.

The government might respond that subsequent land transfers are unnecessary because there are no other religious objects on the contested public property. But this response is unsatisfactory considering that the government prevented other religious objects from being installed, which consequently provides the justification to deny other requests for land. In Buono, had the government permitted the stupa, basic principles of equality would require a transfer of the land underlying the stupa. In this regard, the government can circumvent the Establishment Clause by endorsing religion through the first land transfer and expressing a preference for one religious sect by denying subsequent land transfers to other religious groups, like in Duchesne City.

One might defend the governmental actions in Duchesne City or Buono on the basis that the government may preserve existing religious symbols as memorials while rejecting additional symbolic memorials. ${ }^{293}$ Although a first-installed-first-preserved rule could appear reasonable, such a rule would in effect advance religious preferences. The most historically entrenched permanent symbols have been pervasively Christian. ${ }^{294}$ "The displays almost always represent objects of dominant, or at least less marginalized, religious groups, and thus the failure to find such displays unconstitutional in many circumstances amounts to a de facto establishment of majority religious preferences."295 Thus, allowing a first-installed-first-preserved rule would perpetuate the preference shown for the majoritarian religion.

291. Buono IV, 527 F.3d 758, 769 (9th Cir. 2008), rev'd and remanded sub nom. Salazar v. Buono, 130 S. Ct. 1803 (2010).

292. See id.

293. See Clement, supra note 147, at 254 (pointing out that there are "many secular reasons Congress may have had in seeking to preserve the decades-old private war memorial, while at the same time not objecting to the Park Service's determination that new memorials on the same site were inappropriate.”).

294. See, e.g., supra notes 71, 123. One rare case involved a Buddhist bell. Brooks v. City of Oak Ridge, 222 F.3d 259 (6th Cir. 2000).

295. Frank S. Ravitch, Religious Objects as Legal Subjects, 40 WAKE FOREST L. REV. 1011, 1061 (2005). 


\section{EFFECT OF LAND DISPOSITION}

Even if the government has a secular purpose behind land dispositions, such actions may be invalid if they cause an impermissible effect: conveying a message of governmental endorsement or disapproval of religion. An evaluation of the history and ubiquity of the practice, context and physical setting of the display, and procedural irregularity $^{296}$ involved in land disposition cases leads a reasonable observer to conclude that the government is promoting religion. These considerations militate in favor of removing the religious object, which the government can do without being perceived as inhibiting or disapproving of religion.

\section{A. Endorsing Religion}

\section{History and Ubiquity}

History and ubiquity are among the factors the Court has considered when evaluating the effect of government actions in Establishment Clause cases. ${ }^{297}$ The history and ubiquity of the practice provides the reasonable observer context to assess whether the action conveys a message that the government is approving or disapproving of religion. ${ }^{298}$ The question, as Justice O'Connor framed it, is whether a reasonable observer would view longstanding practices as endorsing religion if they were undertaken for a secular purpose and their religious relevance has dissipated with time. ${ }^{299}$

Courts have noted the longevity of a religious symbol to emphasize its historical significance in establishing that the object has become an accepted part of the community. ${ }^{300}$ In Van Orden, for example, to bolster

296. See, e.g., Lynch v. Donnelly, 465 U.S. 668, 692-94 (1984).

297. Cnty. of Allegheny v. ACLU Greater Pittsburgh Chapter, 492 U.S. 573, 630 (1989) (O’Connor, J., concurring); see also Capitol Square Review \& Advisory Bd. v. Pinette, 515 U.S. 753, 778 (1995) (O’Connor, J., concurring) (inquiring into the "history and administration” of a government practice to determine endorsement).

298. Allegheny, 492 U.S. at 630; see also Pinette, 515 U.S. at 778 (1995) (O’Connor, J., concurring).

299. Allegheny, 492 U.S. at 631.

300. See, e.g., Trunk v. City of San Diego, 660 F.3d 1091, 1092 (9th Cir. 2011) (Bea, J., dissenting from denial of rehearing en banc) (noting that other courts have found that "whether the government has violated the Establishment Clause by erecting or maintaining a religious symbol on public grounds depends on: (1) the government's use of the religious symbol; (2) the context in which that symbol appears; and (3) the history of the symbol while under government control, 
its position that the display was constitutional, the plurality noted that the Ten Commandments monument had existed for forty years without controversy. $^{301}$ Justice Breyer espoused this rationale in Van Orden when he explained that "[i]t was particularly important that the Texas display stood uncontested for forty years. That fact indicated, as a practical matter of degree, that (unlike the Kentucky display [in McCreary]) the Texas display was unlikely to prove socially divisive.”302

This line of argument has carried over to land dispositions, where it contends that land disposition does not convey a message of government endorsement because the religious symbol's longevity demonstrates that its religious message has dissipated. In Buono, the nearly seven decades that the cross had stood persuaded the plurality of its historical meaning: "Time has also played its role. The cross has stood on Sunrise Rock for nearly seven decades before the statute was enacted. By then, the cross and the cause it commemorated had become entwined in the public consciousness.”303

including how long it has stood unchallenged”), cert. denied sub nom. Mount Soledad Mem'l Ass'n v. Trunk, 132 S. Ct. 2535 (2012).

301. See Van Orden v. Perry, 545 U.S. 677, 682 (2005) (plurality opinion). Justice Breyer stated, "I am not aware of any evidence suggesting that [the absence of prior litigation] was due to a climate of intimidation.” Id. at 702 (Breyer, J., concurring). The Seventh Circuit in Mercier made a similar conclusion. See Mercier v. Fraternal Order of Eagles, 395 F.3d 693, 700 (7th Cir. 2005).

302. STEPHEN BREYER, ACTIVE LIBERTY: INTERPRETING OUR DEMOCRATIC CONSTITUTION 123 (2005).

303. Salazar v. Buono, 130 S. Ct. 1803, 1817 (2010) (plurality opinion). Although the plurality in Buono invoked the history of the cross as a justification for its preservation, it failed to reconcile its supposed historical significance with the fact that the cross did not qualify as a National Historic Landmark. See Buono IV, 527 F.3d 758, 769 (9th Cir. 2008). The cross had been replaced throughout the years, and the plaque no longer accompanied it. Id.

Also, interestingly, the government sought to cloak the cross with the prestige and protection bestowed to a National Historic Landmark although it had previously determined granting such designations to religious properties would offend the Establishment Clause. In 1995, the Department of Justice advised the Department of the Interior about the constitutionality of providing historic preservation grants to religious properties. The DOJ concluded that "direct award of historic preservation grants to churches and other pervasively sectarian institutions violates the Establishment Clause of the Constitution.” Constitutionality of Awarding Historic Preservation Grants to Religious Properties to Solicitor of Dep’t of the Interior, Memorandum Op. O.L.C. (Oct. 31, 1995), http://www.justice.gov/olc/doi.24.htm (emphasis omitted). In 2003, the DOJ reversed its policy. Authority of the Dep't of the Interior to Provide Historic Preservation Grants to Historic Religious Properties Such as the Old North Church to Solicitor of Dep't of Interior, Memorandum Op. O.L.C. (Apr. 30, 2003), http://www.usdoj.gov/olc/OldNorthChurch.htm; see also Christen Sproule, Federal Funding for the Preservation of Religious Historic Places: Old North Church and the New Establishment Clause, 3 GEO. J.L. \& PUB. POL'Y 151, 171-73 (2005) (discussing the shift in DOJ policy). 
This line of argument is problematic because it "smacks of bootstrapping." 304 It is equivalent to arguing "the longer the violation, the less violative it becomes. The longer a [religious object] is displayed... , the more the effect is to memorialize rather than sermonize." ${ }^{305}$ Although in Marsh v. Chambers, the Court permitted legislative prayers because of their "unique history,"306 the Court has narrowly applied Marsh by emphasizing that "Marsh plainly does not stand for the sweeping proposition ... that all accepted practices 200 years old and their equivalents are constitutional today."307 Such a reading of Marsh, as the Court explained, "would gut the core of the Establishment Clause.”308

The interpretation that an unchallenged practice signifies community support, however, fails to consider the possibility that longevity of the practice or silence of religious minorities represents "something quite different from disinterest." ${ }^{309}$ Professor Douglas Laycock explains,

It is far more plausible to infer that those who knew and might have complained saw little hope of success in filing a lawsuit.... [Additionally,] it is far more plausible to infer that anyone who knew about the display, objected to it, and thought he could win a lawsuit might have been intimidated, or at least might have thought it was just not worth the cost in hassle and social disapproval to pursue a lawsuit that would produce intense political resistance and no monetary recovery.

\section{As Justice Souter pointed out in Van Orden,}

Suing a State over religion puts nothing in a plaintiff's pocket and can take a great deal out, and even with volunteer litigators to supply time and energy, the risk of social ostracism can be powerfully deterrent. I

\footnotetext{
304. Freedom From Religion Found. v. City of Marshfield, 203 F.3d 487, 495 (7th Cir. 2000) (quoting Gonzales v. N. Twp., 4 F.3d 1412, 1422 (7th Cir. 1993)) (internal quotation marks omitted).

305. Trunk, 629 F.3d at 1122 (quoting Gonzales, 4 F.3d at 1422); see also Van Orden, 545 U.S. at 746-47 (Souter, J., dissenting) (arguing that the passage of time should not impact the constitutionality of the issue).

306. 463 U.S. 783, 791 (1983).

307. Cnty. of Allegheny v. ACLU Greater Pittsburgh Chapter, 492 U.S. 573, 603 (1989); see also EISGRUBER \& SAGER, supra note 263, at 138 (arguing that in some contexts, "tradition and historical pedigree will not save sectarian symbols”).

308. Allegheny, 492 U.S. at 604.

309. Murphy v. Bilbray, 782 F. Supp. 1420, 1433 (S.D. Cal. 1991) (quoting Hewitt v. Joyner, 940 F.2d 1561, 1567 (9th Cir. 1991)).

310. Laycock, supra note 206, at 1224.
} 
doubt that a slow walk to the courthouse, even one that took 40 years, is much evidentiary help in applying the Establishment Clause. ${ }^{311}$

Trunk demonstrates that lack of litigation does not equate to the religious object's acceptance. In Trunk, the Ninth Circuit explained that there was a history of anti-Semitism, particularly in the housing market in La Jolla, where the cross had been erected. ${ }^{312}$ Challenges concerning the constitutionality of the cross began to surface within a decade of Jews and other minorities gaining access to the housing market in La Jolla. ${ }^{313}$ These events suggest that the discrimination in La Jolla "may have stifled complaints about the Memorial early in its lifetime.”314

A reasonable observer who possesses historical knowledge could perceive the government's efforts in Trunk and Buono as endorsing or advancing religion. As the Court stated, "[R]easonable observers have reasonable memories, and our precedents sensibly forbid an observer 'to turn a blind eye to the context in which [the] policy arose."”315 The reasonable observer would know that the site in Trunk was not originally a war memorial and did not acquire physical elements to indicate it was a memorial until late $1989 .{ }^{316}$ Such an observer would be aware that the association chose the site because it believed it to be "a fitting place on which to erect an emblem of faith," and accordingly erected the cross as a tribute to God. ${ }^{317}$ Even when the cross was dedicated as a war memorial in 1954, it was simultaneously dedicated to Jesus Christ. ${ }^{318}$ After the dedication, the site became the setting for Easter services and other religious ceremonies. ${ }^{319}$ Most of the secular events taking place at the site occurred only after legal challenges were initiated in $1996 .{ }^{320}$ Additionally, "[g]iven that the Cross was constructed in La Jolla with a distinctively religious purpose, by La Jolla residents, during the height of this discriminatory period, we cannot ignore that such discrimination is

\footnotetext{
311. Van Orden v. Perry, 545 U.S. 677, 747 (2005) (Souter, J., dissenting).

312. Trunk v. City of San Diego, 629 F.3d 1099, 1121 (9th Cir. 2011), cert. denied sub nom. Mount Soledad Mem’l Ass'n v. Trunk, 132 S. Ct. 2535 (2012).

313. Id. at 1122 .

314. Id.

315. McCreary Cnty. v. ACLU of Ky., 545 U.S. 844, 866 (2005) (second alteration in original) (quoting Santa Fe Indep. Sch. Dist. v. Doe, 530 U.S. 290, 315 (2000)).

316. See Trunk, 629 F.3d at 1118-19.

317. Id. at 1119.

318. Id.

319. Id.

320. Id.
} 
part of the Memorial's history and context and informs the reasonable observer's views." 321 The reasonable observer would also know that the site in Buono had hosted Easter services since 1935 and that no annual Armistice Day or Veterans Day services were held until controversy over the cross arose. ${ }^{322}$

Thus, the longevity of a religious symbol is an unreliable indicator of historical significance and should not mitigate the object's religious significance. ${ }^{323}$ On the contrary, the longer a religious object has been in place the more it solidifies the object's religious message and its sectarian prominence or dominance. Arguments relying on a religious object's longevity fail to recognize that time may in fact undermine support for the object's continued display.

\section{Context and Physical Setting}

The context and physical setting of a religious object is yet another factor relevant to considering the effect of land sales and transfers. Context was significant in Lynch, where Justice O'Connor found no effect of government endorsement. ${ }^{324}$ In Lynch, Justice O’Connor first applied the endorsement test to review the constitutionality of a city's inclusion of a crèche in a display among a Santa Claus, Christmas tree, clown, elephant, and teddy bear. ${ }^{325}$ Justice O'Connor believed that the government's purpose for including the crèche among the display was to celebrate the winter holiday, not promote religion. ${ }^{326}$ Although displaying the crèche among secular objects did not neutralize the religious symbolism of the crèche, such a varied display negated any message of government endorsement of religion. ${ }^{327}$ Similarly, in Allegheny, Justice O'Connor concluded that a menorah did not convey an endorsement of religion because it was displayed next to a Christmas tree and a message saluting liberty. ${ }^{328}$

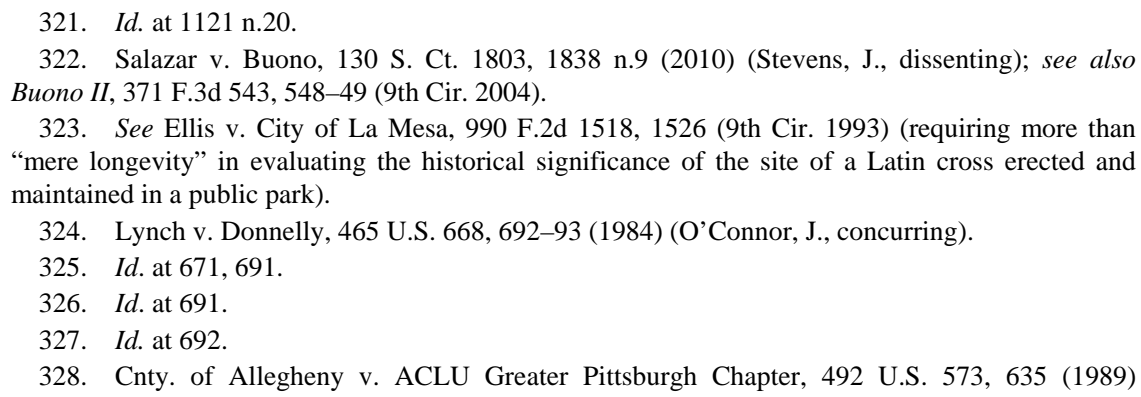


In Capitol Square Advisory \& Review Board v. Pinette, Justice O'Connor applied the reasonable person construct to determine if a cross erected by the Ku Klux Klan in a public square accompanied by a sign disclaiming government sponsorship would convey a message of endorsement. ${ }^{329}$ Justice O'Connor attributed to the reasonable person the knowledge that the cross is a religious symbol and that the square is a public park located near the seat of government. ${ }^{330}$ Her reasonable person also knew that the public square had been used in the past by private speakers ${ }^{331}$ and understood the difference between speech supported by the government and speech permitted by the government as a result of opening the space to private speakers. ${ }^{332}$ Justice O'Connor concluded that the reasonable person would not interpret the Klan's cross as a religious endorsement because the reasonable observer would also read and understand the Klan's disclaimer. ${ }^{333}$ In contrast, notwithstanding the disclaimer in Allegheny, displaying the crèche in "the main and most beautiful part of the building that is the seat of county government" sent an "unmistakable message that [the government] supports and promotes the Christian praise to God that is the crèche's religious message.”334

Similar to the crèche in Allegheny, the physical setting of the displays in Trunk and Buono are likely to convey to a reasonable observer a message of government endorsement. Although the displays rest on private land since the divestiture, the continued display of the religious objects in prominent places may perpetuate the aura of government endorsement. The Seventh Circuit implicitly recognized, by pointing out that the monument was not located in a "particularly privileged location in the aesthetic scheme of the Park," that the location of a monument would affect the Establishment Clause analysis. ${ }^{335}$ The Ten Commandments monument in Mercier was illuminated by a spot light affixed to a rooftop; ${ }^{336}$ the crosses in Trunk and Buono were erected

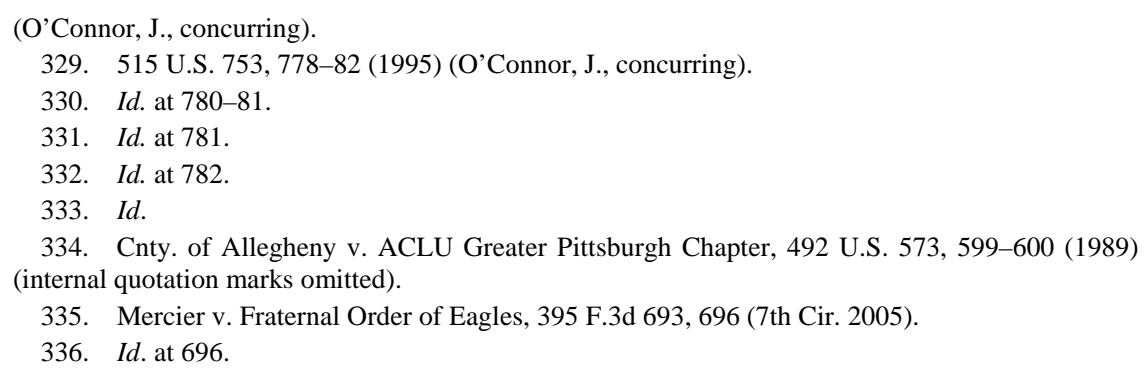


in a place of prominence on a mountain and rock outcropping, respectively, highlighting the religious message of the Latin crosses. ${ }^{337}$ In Trunk, the cross's sheer size-weighing twenty-four tons and standing forty-three feet tall atop a mountain-dominated its surroundings ${ }^{338}$ and towered over thousands of drivers. ${ }^{339}$

The religious message of the cross in Trunk, unlike the crèche in Lynch, is not negated by surrounding secular objects. ${ }^{340}$ While the cross is visible for miles from different perspectives, the secular message conveyed by the inscriptions on the plaques is not visible except to an observer standing near them. ${ }^{341}$ "In fact, the Cross is the only element of the Memorial that can be seen from anywhere except the site of the Memorial itself-including from Interstate 15, which is much farther from Mount Soledad than Interstate 5., ${ }^{342}$

In Buono, there were no other displays to neutralize the religious significance of the cross. Formerly, there had been at one time a sign stating that the cross was intended to commemorate war veterans. ${ }^{343}$ Although Congress appropriated funds for the installment of a replica plaque at the cross, ${ }^{344}$ the plaque was unlikely to neutralize the effect of the cross. Because the cross in Buono, too, stood in an elevated position on top of Sunrise Rock, visible from a distance, ${ }^{345}$ an observer would not be able to read from afar the secular message of a plaque.

Even if equally prominent secular objects were added, their inclusion would not cure the Establishment Clause problem. In McCreary, the county attempted to avoid Establishment Clause violations by surrounding the Ten Commandments poster with secular, historical

337. Trunk v. City of San Diego, 629 F.3d 1099, 1102 (9th Cir. 2011), cert. denied sub nom. Mount Soledad Mem’l Ass’n v. Trunk, 132 S. Ct. 2535 (2012); Salazar v. Buono, 130 S. Ct. 1803, 1811 (2010) (plurality opinion).

338. Trunk, 629 F.3d at 1123.

339. Id. at 1103.

340. See, e.g., Jordan C. Budd, Cross Purposes: Remedying the Endorsement of Symbolic Religious Speech, 82 DENV. U. L. REV. 183, 222 (2004) (arguing that the religious significance of "intrinsically sectarian symbols, such as a cross or Star of David" cannot be muted by including other secular objects).

341. See Trunk, 629 F.3d at 1123.

342. Id.

343. Salazar v. Buono, 130 S. Ct. 1803, 1812 (2010) (plurality opinion).

344. Buono IV, 527 F.3d 758, 770 (9th Cir. 2008) (quoting Department of Defense and Emergency Supplemental Appropriations for Recovery from and Response to Terrorist Attacks on the United States Act, 2002, Pub. L. No. 107-117, § 8137(c), 115 Stat. 2230, 2278-79 (2002)), rev'd and remanded sub nom. Salazar v. Buono, 130 S. Ct. 1803 (2010).

345. Id. at 769 . 
documents. $^{346}$ The Court, however, was not persuaded, believing the county's attempts to be a ruse to mask the county's religious message. ${ }^{347}$ Similarly in Trunk, neither the secular objects, like the bollards, plaques, and pavers later added to the site, ${ }^{348}$ nor the belated secular events, like the Veterans' Day ceremonies, ${ }^{349}$ could diffuse the religious meaning of the cross or the religious activities that have occurred at the site since the cross's installation. ${ }^{350}$ In Lynch and Allegheny, the Court did not hold that the inclusion of other objects muted the religious messages of the crèche and menorah. ${ }^{351}$ "The idea that sacred objects can be robbed of their sacred meaning by placement in a broader display is not in keeping with the general understanding of the nature of religious objects and symbols." 352

Finally, erecting fences and signs disclaiming government ownership after the land has been conveyed to private owners is an inadequate solution "when the problem is not limited to potential confusion regarding the source of the speech." 353 In Allegheny, the Court considered the constitutionality of the crèche and menorah in the context of their surroundings and the effect the posted signs had on government endorsement. ${ }^{354}$ The Court held that the crèche display was unconstitutional despite the fact that the city posted a sign next to the crèche explaining a Roman Catholic organization's ownership of the display. ${ }^{355}$ Rather than finding that the sign mitigated an appearance of government endorsement, the Court concluded that the sign signified the government's endorsement of the organization's religious message. ${ }^{356}$ On the other hand, the city's sign saluting liberty positioned next to the menorah and Christmas tree conveyed cultural diversity rather than a religious endorsement. ${ }^{357}$

\footnotetext{
346. See McCreary Cnty. v. ACLU of Ky., 545 U.S. 844, 856-57 (2005).

347. See id. at $873,881$.

348. Trunk v. City of San Diego, 629 F.3d 1099, 1103 (9th Cir. 2011), cert. denied sub nom. Mount Soledad Mem’l Ass'n v. Trunk, 132 S. Ct. 2535 (2012).

349. Id. at 1119.

350. Id. at $1118,1121$.

351. Ravitch, supra note 295, at 1059; EISGRUBER \& SAGER, supra note 263, at 134.

352. Ravitch, supra note 295, at 1059-60.

353. Mercier v. City of La Crosse, 305 F. Supp. 2d 999, 1012 (W.D. Wis. 2004), rev'd sub nom. Mercier v. Fraternal Order of Eagles, 395 F.3d 693 (7th Cir. 2005).

354. Cnty. of Allegheny v. ACLU Greater Pittsburgh Chapter, 492 U.S. 573 (1989).

355. Id. at 600. The crèche display included a sign stating "This Display Donated by the Holy Name Society.” Id. at 580.

356. Id. at 600 .

357. Id. at 619. The sign next to the forty-five foot Christmas tree that was placed outside next
} 
In circumstances where the land being transferred to private ownership is surrounded by vast public land, it is unlikely that the reasonable observer understands the significance of signs and fencing around the property. For example, as the district court pointed out in Buono III, because the cross is visible by visitors traveling in cars as far as 100 yards away, drivers are unlikely to "quickly recognize"358 that the one acre "donut hole of land" 359 that the cross sits on is private property when it is surrounded by 1.6 million acres of public land. ${ }^{360}$ In the more extreme case of Trunk, there is even a greater likelihood that the reasonable observer will perceive the massive cross as government endorsement. No sign can disclaim government ownership in this instance because the federal government actually owns the seized cross and its surrounding property. ${ }^{361}$ Thus, adding secular objects like signs, fencing, and other monuments is an inadequate measure to disclaim government efforts to preserve a religious symbol that is surrounded by public land, particularly when the reasonable observer has historical knowledge of government involvement.

\section{Deviation in Procedures and Illegality}

Whether there are any deviations from government procedures or regulations for divesting public land via a sale or transfer should also affect the reasonable observer's perception of the transaction's effect. Several cases involve regulatory deviations and congressional anomalies. In Chambers v. City of Frederick, the city did not follow procedures for selling public land and accepted a lower bid. ${ }^{362}$ In Mercier, ${ }^{363}$ Buono, ${ }^{364}$

to the eighteen foot menorah stated: "During this holiday season, the city of Pittsburgh salutes liberty. Let these festive lights remind us that we are the keepers of the flame of liberty and our legacy of freedom.” Id. at 582.

358. Buono III, 364 F. Supp. 2d 1175, 1180 n.7 (C.D. Cal. 2005), aff'd sub nom. Buono IV, 527 F.3d 758 (9th Cir. 2008), rev'd and remanded sub nom. Salazar v. Buono, 130 S. Ct. 1803 (2010).

359. Buono IV, 527 F.3d 758, 768 (9th Cir. 2008), rev'd and remanded sub nom. Salazar v. Buono, 130 S. Ct. 1803 (2010).

360. Buono III, 364 F. Supp. 2d at 1180 n.7.

361. See Trunk v. City of San Diego, 629 F.3d 1099, 1105 (9th Cir. 2011), cert. denied sub nom. Mount Soledad Mem’l Ass’n v. Trunk, 132 S. Ct. 2535 (2012).

362. 373 F. Supp. 2d 567, 572 (D. Md. 2005) (failing to question the city’s noncompliance with requirements for selling public land).

363. Mercier v. Fraternal Order of Eagles, 395 F.3d 693, 697 (7th Cir. 2005).

364. Buono III, 364 F. Supp. 2d at 1180. 
and City of Marshfield, ${ }^{365}$ the land dispositions occurred without the solicitation of other bids.

A reasonable observer would interpret the divestiture of public land to a predetermined recipient without seeking other bids or in lieu of a higher bidder as an endorsement of religion. Rather than endorsing religion directly by displaying the religious monument on public land, the government endorses religion by giving a private group preferential access to display its religious message on property that is surrounded by public land. ${ }^{366}$ In essence, the government sells a platform to a religious group that it knows will continue the religious message of the object. ${ }^{367}$ As the Pinette plurality stated: "Of course, giving sectarian religious speech preferential access to a forum close to the seat of government (or anywhere else for that matter) would violate the Establishment Clause.”368 A reasonable observer would see no meaningful distinction between a government's display of a religious object and its authorization of one private owner's permanent religious display resting in the same location, surrounded by government land. ${ }^{369}$

In addition to failing to seek other bids, the land exchange in Buono occurred outside of established National Park Service procedure. ${ }^{370}$ The Buono plurality embraced the cross's history ${ }^{371}$ but ignored that the original cross and subsequent replacements have existed illegally because they were installed without authorization. ${ }^{372}$ The National Park Service acknowledged this in a letter responding to a request to erect a stupa and through its removal of a replacement cross. ${ }^{373}$ A few days after the Court announced its decision in Buono, the cross at the center of the

365. Freedom From Religion Found. v. City of Marshfield, 203 F.3d 487, 492 (7th Cir. 2000).

366. Mercier v. City of La Crosse, 305 F. Supp. 2d 999, 1003 (W.D. Wis. 2004), rev'd sub nom. Mercier v. Fraternal Order of Eagles, 395 F.3d 693, 704-05 (7th Cir. 2005).

367. See id. at 1012.

368. 515 U.S. 753, 766 (1995) (plurality opinion).

369. Mercier, 305 F. Supp. 2d at 1003.

370. Order Granting Plaintiff's Motion to Enforce Permanent Injunction, Buono III, 364 F. Supp. 2d 1175, 1181 (C.D. Cal. 2005), aff'd sub nom. Buono IV, 527 F.3d 758 (2008), rev'd and remanded sub nom. Salazar v. Buono, 130 S. Ct. 1803 (2010).

371. See Salazar v. Buono, 130 S. Ct. 1803, 1817 (2010) (plurality opinion) (revisiting the cross's history and interpreting the congressional memorial designation as giving recognition to the historical meaning the cross had attained); see also id. at 1822-23 (Alito, J., concurring).

372. Contra Buono IV, 527 F.3d 758, 769 (9th Cir. 2008) (noting originals and replacements have existed illegally, a notion the Supreme Court did not consider), rev'd and remanded sub nom. Salazar v. Buono, 130 S. Ct. 1803 (2010).

373. Id. 
litigation was anonymously removed and later replaced. ${ }^{374}$ The National Park Service removed the replacement cross because it, too, was installed illegally. ${ }^{375}$

Also, congressional irregularities affect a reasonable observer's perceptions. In Buono, although Congress passed four successive acts relating to the cross and received the benefit of the plurality's legislative deference, ${ }^{376}$ the legislative history is devoid of the customary debate attendant to legislative acts. There is no legislative history to show congressional deliberation, particularly regarding the national cross designation $^{377}$ or land transfer. ${ }^{378}$ Given that in each of the successive acts pertaining to the cross the relevant provision dealing with the cross was "buried in a defense appropriations bill," ${ }^{379}$ it is easy to see how those provisions could be enacted without much notice.

A reasonable observer who is aware of the government's noncompliance with its own laws or customary procedures would likely perceive such maneuvers as government endorsement of religion. Moreover, deviations in procedure to effectuate land dispositions can convey a sectarian preference. A reasonable observer would see such

374. Park Service Removes Mojave Cross Replica, CBN.com (May 21, 2010), http://www.cbn.com/cbnnews/us/2010/May/Stolen-Mojave-Desert-Cross-Returned/; Replica Cross Mysteriously Appears in Mojave: Authorities Call it Illegal and Remove it from Federal Preserve, MSNBC.COM (May 20, 2010, 9:04 PM), http://www.msnbc.msn.com/id/37261550.

375. CBN.COM, supra note 374; MSNBC.COM, supra note 374.

376. See Buono, 130 S. Ct. at 1813, 1817 (plurality opinion) (reviewing the four statutes related to the cross).

377. Id. at 1834 (Stevens, J., dissenting).

378. Id. at 1840 (noting that there are "no factual findings, reasoning, or long history of careful legislative adjustments [and] Congress did not devote years of careful study to $\S 8121$, nor did it develop a record of any kind, much less an exhaustive one" (citations omitted) (internal quotation marks omitted)).

379. See id. (citing Buono III, 364 F. Supp. 2d 1175, 1181 (C.D. Cal. 2005), aff'd sub nom. Buono IV, 527 F.3d 758 (2008), rev'd and remanded sub nom. Salazar v. Buono, 130 S. Ct. 1803 (2010)). The prohibition against expending federal funds to remove the cross consisted merely of three lines within an act spanning 712 pages. See Consolidated Appropriations Act-FY 2001, Pub. L. No. 106-554, § 133, 114 Stat. 2763, 2763A-230 (2000). The cross's designation appeared in a few lines in a 126-page act. See Department of Defense and Emergency Supplemental Appropriations for Recovery from and Response to Terrorist Attacks on the United States Act, 2002, Pub. L. No. 107-117, § 8137, 115 Stat. 2230, 2278-79 (2002). The second prohibition against expenditure of federal funds for the cross's removal appeared in two lines of an act consisting of fifty-eight pages. See Department of Defense Appropriations Act, 2003, Pub. L. No. 107-248, § 8065(b), 116 Stat. 1514, 1551 (2002). The provision transferring the land consisted of one paragraph within fifty-six pages of an act. See Department of Defense Appropriations Act, 2004, Pub. L. No. 108-87, § 8121(a), 117 Stat. 1054, 1100 (2003). 
herculean efforts ${ }^{380}$ to save a majoritarian religious symbol as additional government support of majority religions over minority religions. ${ }^{381}$

If anything, the sale... exacerbates the violation because it communicates to nonadherents that not only is the City willing to display a Judeo-Christian symbol on public property, but it is also willing to carve up a public park to [e]nsure that the symbol does not have to be moved or share its space with displays expressing other viewpoints. $^{382}$

The disposition "sends a message to nonadherents that they are outsiders, not full members of the political community, and an accompanying message to adherents that they are insiders, favored members of the political community."383 Thus, after considering the longevity, context, and procedural irregularities of the religious object, a reasonable observer would view the government's privatization of public land as endorsement of religion, and such perceptions can be avoided by removing the religious symbols.

\section{B. Inhibiting or Disapproving of Religion}

While the government must be careful not to endorse religion, it must also take equal care not to inhibit or show disapproval of religion. $^{384}$ Some may criticize requiring the government to remove religious symbols on public land as being unnecessarily secular or even violating the Lemon and endorsement tests by inhibiting or disapproving of religion. It has been argued that when the government acts in a secular manner without regard for the role of religion in society, it actually prefers nonreligion over religion, ${ }^{385}$ harbors a "latent hostility"386

\footnotetext{
380. Buono III, 364 F. Supp. 2d at 1182.

381. See Budd, supra note 340, at 224. As Budd put it:

Accommodations in the remedial context thus should be permitted only if they afford endorsed religious speech no expressive advantage vis $a$ vis competing private viewpoints. To otherwise permit government to project its perceived favoritism into the sphere of private expression will perpetuate rather than dissipate apparent endorsement in the view of a skeptical observer. Id. (footnote omitted).

382. Mercier v. City of La Crosse, 305 F. Supp. 2d 999, 1013 (W.D. Wis. 2004), rev'd sub nom. Mercier v. Fraternal Order of Eagles, 395 F.3d 693 (7th Cir. 2005).

383. Lynch v. Donnelly, 465 U.S. 668, 688 (1984) (O’Connor, J., concurring).

384. See id. at 690; Lemon v. Kurtzman, 403 U.S. 602, 612-13 (1971).

385. In Lynch, the mayor stated, "The people absolutely resent somebody trying to impose another kind of religion on them .... I think the denigration, trying to eliminate these kind [sic] of
} 
or "callous indifference toward religious faith,"387 favors "nontheistic religion/faith,”, 388 or promotes "a religion of secularism.,"389

But these types of arguments misunderstand the Establishment Clause. A "religion of secularism," as defined by the Court, entails "affirmatively opposing or showing hostility to religion, thus 'preferring those who believe in no religion over those who do believe." "390 When the government declines association with religious monuments, it is not preferring those who believe in no religion. Rather, it is merely being silent on the matter of religion. "A secular state, it must be remembered, is not the same as an atheistic or antireligious state. A secular state establishes neither atheism nor religion as its official creed.”391 Affirmative beliefs like Humanism and atheism require positive assertions and are not advanced merely by government restraint in the realm of religion. ${ }^{392}$ Preferring nonreligion requires an affirmative act, such as allowing a display that states that there is no God or Supreme Being. To interpret government silence and inaction as a type of preference for nonreligion would turn the Establishment Clause on its head. Put another way, “[i]f 'non-religion' is, in fact, religion, then every governmental action is an establishment." ${ }^{393}$ This interpretation

things, is a step towards establishing another religion, non-religion that it may be." Donnelly v. Lynch, 525 F. Supp. 1150, 1162 (D.R.I. 1981) (first alteration in original), aff'd, 691 F.2d 1029 (1st Cir. 1982), rev’d, 465 U.S. 668 (1984).

386. Cnty. of Allegheny v. ACLU Greater Pittsburgh Chapter, 492 U.S. 573, 657 (Kennedy, J., concurring in part and dissenting in part).

387. Id. at 664 .

388. McGinley v. Houston, 361 F.3d 1328, 1329-30 (11th Cir. 2004) (rejecting argument that removing religious monument favors nontheistic faith). Similarly, Professors Christopher Eisgruber and Lawrence Sager point out that

[t]here is an opprobrious dimension to the Court's judgment. But that is just a function of constitutional adjudication generally: there will often be a moral dimension to constitutional disputes, and persons on the losing side may understand themselves to have been criticized by an official organ of the state. The social meaning of the [C]ourt's decision does not on this account include the message that anyone is less than a full member of any relevant community.

EISGRUBER \& SAGER, supra note 263, at 129-30.

389. See Sch. Dist. of Abington Twp. v. Schempp, 374 U.S. 203, 225 (1963) (rejecting argument that prohibiting Bible readings at school would promote "a religion of secularism").

390. Id. (quoting Zorach v. Clauson, 343 U.S. 306, 314 (1952)).

391. Allegheny, 492 U.S. at 610.

392. Greater Hous. Chapter of ACLU v. Eckels, 589 F. Supp. 222, 228-31 (S.D. Tex. 1984) (pointing to expert witness testimony stating Humanism rejects beliefs in God, cherishes the powers of man, and is promoted through the symbol known as the Happy Humanist).

393. Marshall, supra note 19, at 542. 
would make it impossible to correct Establishment Clause violations "because every time a violation is found and cured by the removal of the statue or practice that cure itself would violate the Establishment Clause by leaving behind empty space.”394

Moreover, arguments that the government is hostile to religion when it removes a religious symbol or takes a position on secular subjects antithetical to religious tenets have not been successful in the courts. ${ }^{395}$ Los Angeles County, for instance, removed the cross from its official seal in an effort to maintain neutrality in compliance with the Establishment Clause ${ }^{396}$ and as a result, faced litigation alleging that the county's actions were "motivated by [its] disapproval of, and hostility toward, the Christian religion." ${ }^{\text {"397 }}$ The Ninth Circuit concluded that because the county sought to avoid violating the Establishment Clause, the county had a secular purpose. ${ }^{398}$ In light of the fact that the county acted in response to court cases invalidating other municipalities' seals with crosses on them, the court found that a reasonable observer aware of history of the government's actions would not interpret removing the cross as government disapproval of Christianity or religion. ${ }^{399}$

In Catholic League for Religious and Civil Rights v. City \& County of San Francisco ${ }^{400}$ and American Family Ass'n v. City \& County of San Francisco, ${ }^{401}$ the Ninth Circuit considered other cases, although not involving religious symbols, that invoked Lemon's prohibition against the disapproval of religion. In American Family Ass' $n$, the government responded to religious organizations' advertising campaigns against homosexuality by passing resolutions denouncing those ads and their sponsors. ${ }^{402}$ In Catholic League, the city adopted a resolution "urging Cardinal William Levada... to withdraw his discriminatory and defamatory directive that Catholic Charities of the Archdiocese of San

\footnotetext{
394. McGinley v. Houston, 361 F.3d 1328, 1332 (11th Cir. 2004).

395. See GRIFFIN, supra note 137, at 78-79 (discussing the courts' approach to cases involving Lemon's disapproval prong); see also Catholic League for Religious \& Civil Rights v. San Francisco, 567 F.3d 595 (9th Cir. 2009), aff'd en banc, 629 F.3d 1043 (9th Cir. 2010); Vasquez v. Los Angeles Cnty., 487 F.3d 1246 (9th Cir. 2007); Am. Family Ass'n v. City \& Cnty. of San Francisco, 277 F.3d 1114 (9th Cir. 2002).

396. Vasquez, 487 F.3d at 1248.

397. Id.

398. Id. at 1255-56.

399. Id. at 1257 .

400. 567 F.3d 595 (9th Cir. 2009), aff'd en banc, 629 F.3d 1043 (9th Cir. 2010).

401. 277 F.3d 1114 (9th Cir. 2002).

402. Id. at 1118-20.
} 
Francisco stop placing children in need of adoption with homosexual households." ${ }^{403}$ The plaintiffs in both cases argued that the government's defense of homosexuals was hostile to religious beliefs that homosexuality is deviant and immoral, ${ }^{404}$ but the Ninth Circuit upheld the city's actions because it recognized that promotion of gay rights and same-sex adoption as well as prevention of hate crimes against homosexuals can have a "secular dimension." that a reasonable observer would not interpret the resolutions, when viewed in the context of the city's other actions defending the rights of homosexuals, as primarily disapproving of or inhibiting religion. ${ }^{406}$ As the court explained, a "belief can have both religious and secular dimensions; the government is not stripped of its secular purpose simply because the same concept can be construed as religious.... [I]f consistency with religious beliefs is not endorsement of religion, inconsistency is not hostility to it." ${ }^{407}$

Therefore, actions taken on secular issues, such as removing religious symbols from public land, that may conflict with religious beliefs nonetheless comport with the Establishment Clause and do not establish a "religion of secularism" or hostility toward religion.

\section{EXCESSIVE GOVERNMENT ENTANGLEMENT}

Government entanglement, whether evaluated as an individual test in Lemon $^{408}$ or collapsed into the endorsement test's effect prong, ${ }^{409}$ is another relevant consideration for determining the constitutionality of land sales and transfers involving religious objects. To determine whether a government act implicates excessive government entanglement, the Court has "examine[d] the character and purposes of the institutions that are benefitted, the nature of the aid that the State

\footnotetext{
403. Catholic League, 567 F.3d at 598.

404. Id. at 602; Am. Family Ass'n, 277 F.3d at 1122.

405. Catholic League, 567 F.3d at 602; see also Am. Family Ass'n, 277 F.3d at 1121-22 (holding that the city had a secular purpose for discouraging violence against gays and that the resolution had a secular effect, not a primary effect of inhibiting or disapproving of religion).

406. Catholic League, 567 F.3d at 606; Am. Family Ass'n, 277 F.3d at 1122.

407. Catholic League, 567 F.3d at 603.

408. Lemon v. Kurtzman, 403 U.S. 602, 612-13 (1971).

409. Even when government entanglement was "first explicitly articulated in Walz v. Tax Commission... [it] could easily have been construed as simply a pragmatic rephrasing of the 'primary effect' test." Kenneth F. Ripple, The Entanglement Test of the Religion Clauses-A Ten Year Assessment, 27 UCLA L. REV. 1195, 1197 (1980).
} 
provides, and the resulting relationship between the government and the religious authority." ${ }^{410}$ Although some argue that the entanglement prong should be disregarded, ${ }^{411}$ the Court has invalidated laws that administratively entangle the government by requiring a "comprehensive, discriminating, and continuing state surveillance"412 and has expressed concerns about laws that engender political divisiveness. ${ }^{413}$ The government's inclusion of restrictive covenants and retention of reversionary interests in land dispositions potentially entangles the government with religion by continuing government involvement in monitoring and enforcing these provisions, and by engendering political divisiveness.

\section{A. Restrictive Covenants}

Few would disagree that a government's explicit mandate to retain a religious object on land it conveys to a private owner would excessively entangle the government in religion. The more contentious issue is whether a restrictive covenant that requires maintenance of a memorial effectively mandates a private owner to retain the religious object itself. Resolving this issue depends on statutory construction and common sense.

Considering the facts in Buono, a reasonable observer could view the land transfer and legislative acts as a means to preserve the cross. The land transfer act requires that the new owner maintain the property as a

410. Lemon, 403 U.S. at 615.

411. Aguilar v. Felton, 473 U.S. 402, 429-30 (1985) (O’Connor, J., dissenting) (expressing "reservations" about the entanglement prong), overruled by Agostini v. Felton, 521 U.S. 203 (1997); Roemer v. Bd. of Pub. Works, 426 U.S. 736, 768-69 (1976) (White, J., concurring) (describing the entanglement prong as "unnecessary," “insolubly paradoxical," and "curious and mystifying”); Lemon, 403 U.S. at 661-71 (White, J., dissenting) (criticizing the entanglement element as "curious and mystifying”); see also Kristi L. Bowman, An Empirical Study of Evolution, Creationism, and Intelligent Design Instruction in Public Schools, 36 J.L. \& EDUC. 301, 313 (2007) ("[T]he third prong (entanglement) is practically forgotten, although it has not been officially, uniformly disregarded.”); Rupal M. Doshi, Note, Nonincorporation of the Establishment Clause: Satisfying the Demands of Equality, Pluralism, and Originalism, 98 GEO. L.J. 459, 479 (2010). But see Friedman v. Bd. of Cnty. Comm'rs, 781 F.2d 777, 780 n.3 (10th Cir. 1985) ("In addition, we must caution that courts not be too easily convinced that the administrative or political entanglement demonstrated in a given case is de minimis because of the limited monetary value of the government's involvement. .. . Expense is not the only path to entanglement. And, even if it were, we must remember that it is no defense to say that the government's action represents a 'relatively minor encroachment on the First Amendment.”' (quoting Sch. Dist. of Abington Twp. v. Schempp, 374 U.S. 203, 225 (1963))).

412. Lemon, 403 U.S. at 619.

413. Id. at $622-24$. 
war memorial. ${ }^{414}$ Although the government argued in Buono that the act is ambiguous as to whether the cross must be part of the required memorial, ${ }^{415}$ it is logical to read the transfer act as requiring maintenance of the cross because Congress had specifically designated the cross as a memorial $^{416}$ and required funds to install a replica of the plaque. ${ }^{417}$ First, Congress authorized up to $\$ 10,000$ for a replica of the cross and plaque. It would make little sense that the land transfer act's requirement to preserve the memorial meant anything other than the cross's preservation after such expenditure of tax dollars and effort to acquire the replica. Second, there is no ambiguity that Congress intended "memorial" to mean the cross when, on the heels of the district court's injunction, it passed the act forbidding the use of federal funds to "dismantle national memorials commemorating United States participation in World War I." ${ }^{\prime 18}$ It is strange to suggest that the word memorial-the meaning of which was clear in the two prior acts-should suddenly become ambiguous in the land transfer act; there has been no subsequent act to supersede the designation of the cross as a national memorial. ${ }^{419}$ Further, statutory construction requires that the land transfer act's reference to a war memorial mean the cross: "[An] accepted rule of construction is that ambiguities in a newly enacted statute are to be resolved in such a fashion as to make the statute, not only internally consistent, but also compatible with previously enacted laws." ${ }^{, 20}$ Finally, it often takes a congressional act to abolish a national memorial. ${ }^{421}$ Because no subsequent act has changed the cross's designation as a memorial, the cross must still be the memorial referred to in the land transfer act.

414. Department of Defense Appropriations Act, 2004, Pub. L. No. 108-87, § 8121(e), 117 Stat. 1054, 1100 (2003).

415. See Brief for the Petitioners at 33, Salazar v. Buono, 130 S. Ct. 1803 (2010) (No. 08-472), 2009 WL 1526915, at *33 (arguing that the Department of Defense Appropriations Act of 2004 "does nothing 'to preserve and maintain the cross"”).

416. The memorial was previously officially designated as the "White Cross World War I Memorial.” Buono IV, 527 F.3d 758, 770 (9th Cir. 2008), rev’d and remanded sub nom. Salazar v. Buono, 130 S. Ct. 1803 (2010).

417. See Department of Defense and Emergency Supplemental Appropriations for Recovery from and Response to Terrorist Attacks on the United States Act, 2002 Pub. L. No. 107-117, § 8137(c), 115 Stat. 2230, 2278-79 (2002).

418. Buono IV, 527 F.3d at 771 (quoting Department of Defense Appropriations Act, 2003, Pub. L. No. 107-248, § 8065(b), 116 Stat. 1514, 1551 (2002)).

419. See Mary Jean Dolan, Salazar v. Buono: The Cross Between Endorsement and History, 105 Nw. U. L. ReV. ColloQuY 42, 51 n.59 (2010) (“[A]bolishing National Memorial status frequently has entailed specific congressional action.”).

420. ANTONIN SCALIA, A MATTER OF INTERPRETATION 16 (Amy Gutmann, ed., 1997).

421. Dolan, supra note 419, at 51 n.59. 
The argument that a restrictive covenant requiring a memorial's maintenance does not include the religious object itself is disingenuous. In most instances, the religious object and land underlying it are sold, without seeking other bidders or accepting higher bids, to the object's original donor or to someone else who expressed an interest in maintaining the religious object. In Mercier, the government sold the Ten Commandments monument and the land beneath it to the local Eagles chapter that originally donated the monument ${ }^{422}$ without soliciting other bids; ${ }^{423}$ similarly, in Chambers the government did so despite having received higher bids. ${ }^{424}$ In Buono, without soliciting other bids, the federal government transferred the cross and its surrounding land to the Veterans of Foreign Wars, which initially erected the cross, and exchanged land with Mr. Sandoz, the individual who erected the cross in its current form. ${ }^{425}$ Also, in City of Marshfield, the government failed to solicit bids ${ }^{426}$ and sold the Christ statue and land beneath it to the Henry Praschak Memorial Fund, Inc., ${ }^{427}$ established in honor of the person who donated the picnic tables and grills for a comfort station around the statue. $^{428}$ Similarly, in Duchesne City, the government sold land along with the monument of the Ten Commandments to the family that had originally donated the monument. ${ }^{429}$

Selling the religious object to its donor most likely ensures that the object will be maintained because the donor obviously attached significance to the object in the first place. For instance, in Mercier, the government made the "practical" decision to sell the religious monument and the underlying land to the Eagles, the donor, as the government was interested in having the monument maintained. The nearby location of the monument to the Eagles chapter made its maintenance convenient for

422. See Mercier v. Fraternal Order of Eagles, 395 F.3d 693, 705 (7th Cir. 2005).

423. Id. at 697 .

424. Chambers v. City of Frederick, 373 F. Supp. 2d 567, 572 (D. Md. 2005).

425. Buono III, 364 F. Supp. 2d 1175, 1180 (C.D. Cal. 2005), aff'd sub nom. Buono IV, 527

F.3d 758 (9th Cir. 2008), rev'd and remanded sub nom. Salazar v. Buono, 130 S. Ct. 1803 (2010).

426. Freedom From Religion Found. v. City of Marshfield, 203 F.3d 487, 492 (7th Cir. 2000).

427. See id. at 489-90.

428. Id. (implying that the Henry Praschak Memorial Fund was so named because Henry Praschak donated the picnic tables and grills surrounding the monument).

429. Summum v. Duchesne City, 340 F. Supp. 2d 1223, 1225 (D. Utah 2004), rev'd, 482 F.3d 1263 (10th Cir. 2007), vacated, 555 U.S. 1210 (2009). 
the Eagles. ${ }^{430}$ "It was a surprise to no one when the [Eagles] chose to keep the monument in its present location."

Even if a restrictive covenant does not explicitly require the retention of the religious object, any covenant requiring some type of maintenance of the property likely suggests to a buyer that the government intends for the status quo-including the religious object-to continue. A requirement to maintain any memorial, even if not the religious object, structures an incentive for the new owner to maintain the current religious object rather than expend funds to dismantle the current memorial and erect a new one in its place.

In Paulson v. City of San Diego, the Ninth Circuit invalidated a prior sale of a cross because the city's consideration of the bid price and financial capability to maintain the "historic war memorial" in selecting a buyer gave an unfair advantage to those seeking to promote the city's sectarian message. ${ }^{432}$ The Ninth Circuit explained:

Suppose that two similarly situated bidders-Bidder \# 1 and Bidder \# 2 - each had the minimum acceptable amount of $\$ 35,000$ to bid on the project, and Bidder \# 1 proposed to retain the cross, while Bidder \# 2 proposed to construct a secular memorial. The structure of the sale ensured that Bidder \# 1 would be awarded the land. Bidder \# 1 could bid the full $\$ 35,000$ and still demonstrate the financial capability to maintain a historic war memorial because the City would subsidize the cost of Bidder \# 1's proposed memorial by conveying the cross. Bidder \# 2 could not compete successfully with Bidder \# 1: If Bidder \# 2 matched Bidder \# 1's bid, then Bidder \# 2 could not demonstrate the financial capability to maintain a historic war memorial, because all of Bidder \# 2's resources would have been dedicated to the bid price, and none would have been reserved to fund removal of the cross and construction of a new memorial. Alternatively, Bidder \# 2 could reserve the money needed to remove the cross and construct the new memorial. But that option would eliminate Bidder \# 2 from the process, because Bidder \#2's bid in that instance would fall below the minimum acceptable bid. ${ }^{43}$

Paulson demonstrates that when a governmental body conditions the sale of land and a religious object on a particular use, bidders who are

430. See Mercier v. Fraternal Order of Eagles, 395 F.3d 693, 705 (7th Cir. 2005).

431. Mercier v. City of La Crosse, 305 F. Supp. 2d 999, 1014 (W.D. Wis. 2004) ("Every La Crosse citizen recognizes the sale to the Order [of the Eagles] was about preserving the monument's religious message in the park.”), rev'd sub nom. Mercier v. Fraternal Order of Eagles, 395 F.3d 395, 693 (7th Cir. 2005).

432. 294 F.3d 1124, 1132-33 (9th Cir. 2002).

433. Id. at 1133 . 
interested in preserving the religious object receive for free the means to continue the government's sectarian message. ${ }^{434}$

Even assuming arguendo that a restrictive covenant cannot be interpreted to require retention of the religious object, a restrictive covenant that generally requires a particular use for the conveyed land would still entangle the government. The Court has warned about "programs, whose very nature is apt to entangle the state in details of administration." 435 In Lemon, the Court invalidated state aid to parochial schools in part because the program entailed "continuing state surveillance" to ensure compliance. ${ }^{436}$ Although the inspection in Lemon related more specifically to religious content, ${ }^{437}$ a covenant that mandates maintaining a memorial necessitates the government to monitor the private owner's compliance, which would continue state action in perpetuity.

\section{B. Reversionary Interests}

The government further perpetuates state action when it retains a reversionary interest in conveyed land because the land on which the religious monument or memorial rests may revert to the government's ownership. Not only must the government monitor the new owner's compliance with the restrictive covenant, but it must also act to enforce the covenant when the new owner fails to meet its obligation. A reversionary interest in the land undermines the government's disassociation from the religious monument, which purportedly motivated the land sale in the first place.

Imposing a requirement on the private owner to maintain the property for a particular use would allow the government to retain "complete present control." 438 For example, in Hampton v. City of Jacksonville, a city sold golf courses that were previously segregated to private owners for fair market value. ${ }^{439}$ Although there was no evidence of bad faith, ${ }^{440}$ the court nonetheless found that state action continued

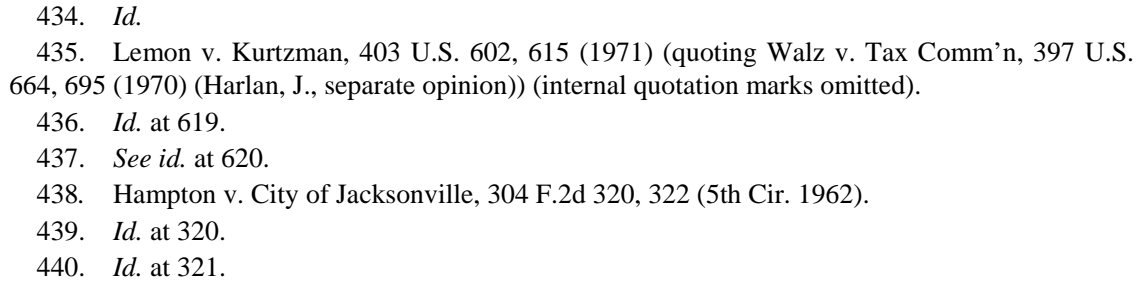


because the city included a reversionary clause in the sale that provided the property would revert to the city if it were used for any purpose other than a golf course. ${ }^{441}$ The court in Hampton considered such schemes involving reversionary clauses as no different from a long term lease that permits the government to cancel if the owner fails to carry out the purpose. $^{442}$

Additionally, entanglement may result from the government retaining an easement on a parcel. In Buono, the government essentially retained an easement over the newly privatized land. ${ }^{443}$ Section 8121 of the land exchange legislation provides that "[n]otwithstanding the conveyance of the property under this subsection, the Secretary shall continue to carry out the responsibilities of the Secretary under such section 8137." 444 The Secretary, pursuant to $\S 8137$, must "use not more than $\$ 10,000$ of funds available for the administration of the Mojave National Preserve to acquire a replica of the original memorial plaque and cross placed at the national World War I memorial . . . and to install the plaque in a suitable location on the grounds of the memorial."445 The government thereby retained at least an easement to allow it to install a plaque, which evinced the government's failure to sever its association with this religious symbol. Because both a restrictive covenant to maintain a memorial and a reversionary clause entails ongoing government surveillance, the government should remove the religious object to avoid government entanglement with religion.

\section{Political Divisiveness}

A land disposition without restrictive covenants or reversionary interests could still excessively entangle the government because of political divisiveness. As early as Everson v. Board of Education, ${ }^{446}$

\footnotetext{
441. Id. at 322 .

442. Id. at 322-23.

443. See Buono IV, 527 F.3d 758, 780 (9th Cir. 2008), rev'd and remanded sub nom. Salazar v. Buono, 130 S. Ct. 1803 (2010).

444. Department of Defense Appropriations Act, 2004, Pub. L. No. 108-87, § 8121(a), 117 Stat. 1054, 1100 (2003).

445. Department of Defense and Emergency Supplemental Appropriations for Recovery from and Response to Terrorist Attacks on the United States Act, 2002, Pub. L. No. 107-117, § 8137(c), 115 Stat. 2230, 2278-79 (2001).

446. 330 U.S. 1, 26-27 (1947) (Jackson, J., dissenting) (reviewing the constitutionality of township's reimbursement for transportation of children to parochial schools).
} 
members of the Court have recognized the divisive effect of religion in the public sphere. As Justice Jackson articulated:

[T] he effect of the religious freedom Amendment to our Constitution was to take every form of propagation of religion out of the realm of things which could directly or indirectly be made public business. ... . It was intended not only to keep the states' hands out of religion, but to keep religion's hands off the state, and, above all, to keep bitter religious controversy out of public life ....

In Lemon, the Court considered the potential for political divisiveness ${ }^{449}$ as part of its entanglement analysis: "A broader base of entanglement of yet a different character is presented by the $\mathrm{d}[\mathrm{i}]$ visive political potential of these state programs." 450 The Lemon Court assumed that the issue of state assistance for parochial schools would prompt substantial political activity in a community with high enrollment in church-related schools. ${ }^{451}$

448. Id.

449. For a discussion about the origins of the political divisiveness argument, see Richard W. Garnett, Religion, Division, and the First Amendment, 94 GEO. L.J. 1667, 1681-83 (2006).

450. Lemon v. Kurtzman, 403 U.S. 602, 622 (1971); see also Aguilar v. Felton, 473 U.S. 402, 417 (1985) (Powell, J., concurring) (discussing that “the potential for such divisiveness" provided "a strong additional reason” to invalidate the government's programs), overruled by Agostini v. Felton, 521 U.S. 203 (1997); Wolman v. Walter, 433 U.S. 229, 259 (1977) (Marshall, J., concurring in part and dissenting in part) (expressing concern for the "dangers of political 'divisiveness on religious lines””), overruled by Mitchell v. Helms, 530 U.S. 793 (2000); Comm. for Pub. Educ. \& Religious Liberty v. Nyquist, 413 U.S. 756, 796 (1973) (warning that competition among religious groups to "gain or maintain the support of government" may “occasion[] considerable civil strife”); Walz v. Tax Comm’n, 397 U.S. 664, 694 (1970) (Harlan, J., separate opinion) (“What is at stake as a matter of policy [in Establishment Clause cases] is preventing that kind and degree of government involvement in religious life that, as history teaches us, is apt to lead to strife and frequently strain a political system to the breaking point.”).

451. Lemon, 403 U.S. at 622. Some argue that Justice Burger failed to buttress the political divisiveness test in Lemon with any historical support. See, e.g., Edward McGlynn Gaffney, Jr., Political Divisiveness Along Religious Lines: The Entanglement of the Court in Sloppy History and Bad Public Policy, 24 ST. LOUIS U. L.J. 205, 214 (1981). But other scholars, though skeptical of the entanglement test, have acknowledged that "the 'excessive entanglement' conception has long been recognized as one of the core strengths of our democratic society. Madison recognized the theoretical necessity of confining religion and civil government to their own respective spheres; de Tocqueville observed the salutary consequences of adherence to that standard." Ripple, supra note 409, at 1238 (footnote omitted). Likewise, Professor Richard Garnett traced the foundations for the political divisiveness test to Madison, who warned “'intermedd[ling] with Religion' by government can only 'destroy ... moderation and harmony' and is an 'enemy of the public quiet.”' Garnett, supra note 449, at 1681 (alterations in original) (quoting JAMES MADISON, MEMORIAL AND REMONSTRAnCE AgAinst Religious Assessments (1785)). 
Some Justices have suggested that the entanglement prong should be confined to administrative entanglement, ${ }^{452}$ but have acknowledged that "[p]olitical divisiveness is admittedly an evil addressed by the Establishment Clause." ${ }^{453}$ Despite appeals to eliminate political divisiveness as a factor, the support for a political divisiveness test can be found in cases beyond its origins in parochial-aid situations. ${ }^{454}$ In one such case, Lee v. Weisman, the Court invalidated nonsectarian school prayers at a graduation. ${ }^{455}$ Although Justice Kennedy grounded his opinion in Weisman in the dangers of coercion, the concept of political divisiveness appeared to inform his discussion of a pluralistic society. ${ }^{456}$ Justice Blackmun, in his concurrence, expressed fear that "mixing of government and religion can be a threat to free government, even if no one is forced to participate" and explained that "[o]nly '[a]nguish, hardship and bitter strife' result 'when zealous religious groups struggl[e] with one another to obtain the Government's stamp of approval., ${ }^{\text {w5 }}$

452. See, e.g., Zelman v. Simmons-Harris, 536 U.S. 639, 662 n.7 (2002) (rejecting "the invisible specters of 'divisiveness' and 'religious strife'”); Agostini v. Felton, 521 U.S. 203, 233-34 (1997) (concluding that divisiveness and "administrative cooperation," without more, were insufficient to create entanglement); Lynch v. Donnelly, 465 U.S. 668, 689 (1984) (O’Connor, J., concurring) (stating that political divisiveness "should not be an independent test of constitutionality"). For other criticisms of political divisiveness as a consideration in determining Establishment Clause violations, see Clement, supra note 147, at 245; Gaffney, supra note 451, at 236 (arguing that the political divisiveness test lacks historical support and promotes bad public policy and bad theology); Garnett, supra note 449, at 1670 (concluding that although political divisiveness concerns are "real and reasonable does not mean that they can or should supply the enforceable content of the First Amendment's prohibition on establishments of religion”); Ripple, supra note 409, at 1217 (arguing that the entanglement standard is vulnerable to judicial subjectivity).

For scholarship supporting political divisiveness as a factor in Establishment Clause evaluations, see Stephen M. Feldman, Divided We Fall: Religion, Politics, and the Lemon Entanglements Prong, 7 FIRST AMEND. L. REV. 253, 260 (2009) (utilizing political theory, social science, and history to defend the political divisiveness factor); David R. Scheidemantle, Note, Political Entanglement as an Independent Test of Constitutionality Under the Establishment Clause, 52 Fordham L. REV. 1209, 1213 (1986) ("The political entanglement test should be capable of striking down [politically divisive legislation] even if it passes scrutiny under the other prongs.”).

453. Lynch, 465 U.S. at 689 (O’Connor, J., concurring); see also Garnett, supra note 449, at 1700 (pointing out that Justice O'Connor's endorsement test is similar to the political divisiveness consideration).

454. See Trunk v. City of San Diego, 629 F.3d 1099, 1123 (9th Cir. 2011), cert. denied sub nom. Mount Soledad Mem'l Ass'n v. Trunk, 132 S. Ct. 2535 (2012).

455. 505 U.S. 577, 584-86 (1992).

456. See Garnett, supra note 449 , at 1701 ("The decision owes as much as any post-Lemon opinion to claims and predictions about politics, division, and religion.”).

457. Weisman, 505 U.S. at 606-07 (Blackmum, J., concurring) (second and third alterations in original) (quoting Engle v. Vitale, 370 U.S. 421, 429 (1962)). 
Similarly, political divisiveness is relevant to religious display cases. In McCreary, Justice Souter, writing for the majority, was concerned about the "civic divisiveness that follows when the Government weighs in on one side of the religious debate."458 In his controlling concurring opinion in Van Orden, Justice Breyer focused on the Establishment Clause's "basic purpose[]" of "avoid[ing] that divisiveness based upon religion that promotes social conflict, sapping the strength of government and religion alike.” ${ }^{459}$ In that same case, Justice Stevens provided even greater support for examining political divisiveness in Establishment Clause cases by referring to the "Government's obligation to avoid divisiveness and exclusion in the religious sphere." 460 Most recently, the Buono plurality implicitly acknowledged political divisiveness as a consideration when it cited to the portion of Justice Breyer's concurrence in Van Orden that expressed fear that removing the Ten Commandments monument could "create the very kind of religiously based divisiveness that the Establishment Clause seeks to avoid." 461

Although the Van Orden and Buono pluralities used it to justify retaining the religious symbol, they nonetheless relied on political divisiveness as a consideration. And as Dean Erwin Chemerinsky points out, “[a]ccepting Breyer's goal of preventing divisiveness should lead to a robust application of the Establishment Clause-the opposite of his conclusion in Van Orden." 462

Because "political division along religious lines was one of the principal evils against which the First Amendment was intended to protect," ${ }^{463}$ the concern about political divisiveness should be relevant to land disposition cases. "The argument for government agnosticism is that, unlike government endorsement of any particular religious proposition, it is not in principle impossible for everyone to agree to it." 464 Government display of religious objects and the sale of land that perpetuate the object's presence are sources of tremendous divisiveness. As Justice Brennan warned, "the Court should not blind itself to the fact

\footnotetext{
458. McCreary Cnty. v. ACLU of Ky., 545 U.S. 844, 876 (2005).

459. Van Orden v. Perry, 545 U.S. 677, 698 (2005) (Breyer, J., concurring).

460. Id. at 709 (Stevens, J., dissenting) (emphasis added).

461. Salazar v. Buono, 130 S. Ct. 1803, 1817 (2010) (plurality opinion) (quoting Van Orden, 545 U.S. at 704 (Breyer, J., concurring)).

462. Erwin Chemerinsky, Why Justice Breyer Was Wrong in Van Orden v. Perry, 14 WM. \& MARY BILL OF RTS. J. 1, 4 (2005).

463. Lemon v. Kurtzman, 403 U.S. 602, 622 (1971).

464. Koppelman, supra note 237, at 735.
} 
that because communities differ in religious composition, the controversy over whether local governments may adopt religious symbols will continue to fester." ${ }^{\text {"65 }}$ The dissent in Lynch pointed out that although there was no apparent civil strife prior to the suit challenging the government's display of the crèche, the suit "unleashed powerful emotional reactions which divided the City along religious lines." 466 The cross in Trunk "has long since become a flashpoint of secular and religious divisiveness," 467 engendering twenty years of litigation. Similarly, in Jewish War Veterans of the United States v. United States, "emotions were running high," provoking over 3,200 letters about the cross and "ignit[ing] a fuse among local residents" who used their political strength to persuade their senator to act. ${ }^{468}$ In other cities, the

465. Lynch v. Donnelly, 465 U.S. 668, 703-04 (1984) (Brennan, J., dissenting).

466. Id. at 702-03. The district court reviewed many letters from the community that reflected a sentiment that the ACLU was engaging in "petty" behavior by initiating a law suit over a central Christian symbol, rather than having the plaintiff who was offended by the crèche avoid the park where the crèche was displayed. Donnelly v. Lynch, 525 F. Supp. 1150, 1162 (D.R.I. 1981), aff'd, 691 F.2d 1029 (1st Cir. 1982), rev'd, 465 U.S. 668 (1984). The majority of the letters expressed outrage and indignation with the "minority's" interference with the "majority's" choice of objects to display. Id. at 1161-62.

Ten local clergypersons jointly issued the following statement in response to the mayor's statements denouncing the legal challenge of the crèche:

We clergy of several religious traditions wish to express a pastoral concern growing out of the controversy surrounding the display of a nativity scene with city funds in Pawtucket. Our concerns are several noted below. While the festivities, lights and generation of good will in this season have roots in both religion and secular tradition, the cr[è]che is a specifically religious symbol. Our country, while deeply influenced by the Judeo-Christian heritage, is not itself Judeo-Christian but is pluralistic, consisting of many rich religious traditions and recognizing the value of all. Government in our country, wisely recognizing the diversity of these traditions, was set up to steer clear of embracing any, while protecting the religious freedom of all. We as pastors have a responsibility to educate our people in the history of religious strife and the futility of imposing religious beliefs on the human conscience. The specifically religious observance of this holiday period belongs in our homes and in our churches and synagogues. Although there are public recognitions of this glad season, they should be confined to those symbols and traditions which are not identified with any one group. We call upon our public officials not to exploit the strong sentiments associated with religious festivals and divide majority from minority. Rather, we hope they will rise to a statesperson-like position and avoid the insensitivity of foisting upon others any specific religious traditions. In this way, the true joy of the season can be appreciated by and made meaningful to the widest diversity of people.

Id. at 1160 n.17.

467. Trunk v. City of San Diego, 629 F.3d 1099, 1122 (9th Cir. 2011), cert. denied sub nom. Mount Soledad Mem’l Ass'n v. Trunk, 132 S. Ct. 2535 (2012); see also Gonzales v. N. Twp., 4 F.3d 1412, 1415 (7th Cir. 1993) (discussing ministerial associations' objections to crucifix because "[t]he religious symbol which was erected with the intention of uniting [the] community in reality has proved divisive both between and within religious groups." (alterations in original)).

468. 695 F. Supp. 3, 5-6 (D.D.C. 1988). 
battle over religious symbols aroused as many as 10,000 people to march in the streets. ${ }^{469}$ As in Buono, the issue of preserving a religious symbol can prompt immediate political activity, possibly extending beyond the community to Congress. Congress reacted to the litigation in Buono over the Latin cross by declaring the cross a memorial, ${ }^{470}$ twice prohibiting public funds to be used for its removal to forestall compliance with the district court injunction, ${ }^{471}$ appropriating $\$ 10,000$ for a replica plaque, ${ }^{472}$ and passing the land exchange act. ${ }^{473}$

Perhaps the ACLU's observation best describes the divisiveness of government religious endorsement:

Of all the issues the ACLU takes on-reproductive rights, discrimination, jail and prison conditions, abuse of kids in the public schools, police brutality, to name a few-by far the most volatile issue is that of school prayer. Aside from our efforts to abolish the death penalty, it is the only issue that elicits death threats. ${ }^{474}$

In Santa Fe Independent School District v. Doe ${ }^{475}$ for example, although the court tried to protect anonymous plaintiffs from harassment, once the plaintiffs' identities were discovered, someone made death threats and killed their dog. ${ }^{476}$ In another case, plaintiffs who challenged religious meetings in the public schools suffered harassment and the destruction of their home. ${ }^{477}$ Even children have been the subjects of threats. ${ }^{478}$ One

469. Slaven, supra note 10 , at 652-53.

470. Buono IV, 527 F.3d 758, 770 (9th Cir. 2008) (quoting Department of Defense and Emergency Supplemental Appropriations for Recovery from and Response to Terrorist Attacks on the United States Act, 2002, Pub. L. No. 107-117, § 8137, 115 Stat. 2230, 2278-79 (2002)), rev'd and remanded sub nom. Salazar v. Buono, 130 S. Ct. 1803 (2010).

471. Id. at 769 (quoting Consolidated Appropriations Act-FY 2001, Pub. L. No. 106-554, § 133, 114 Stat. 2763, 2763A-230 (2000)); id. at 771 (quoting Department of Defense Appropriations Act, 2003, Pub. L. No. 107-248, § 8065(b), 116 Stat. 1519, 1551 (2002)).

472. Id. at 770 (quoting Department of Defense and Emergency Supplemental Appropriations for Recovery from and Response to Terrorist Attacks on the United States Act, $2002 \S 8137)$.

473. Id. at 771 (quoting Department of Defense Appropriations Act, 2004, Pub. L. No. 108-87, § 8121(a)-(e), 117 Stat. 1054, 1100 (2003)).

474. Lee v. Weisman, 505 U.S. 577, 607 n.10 (Blackmun, J., concurring) (quoting Michele A. Parish, Graduation Prayer Violates the Bill of Rights, UTAH BAR. J., June/July 1991, at 19).

475. 530 U.S. 290 (2000).

476. Laycock, supra note 206, at 1224 .

477. See id. at 1225 (citing Bell v. Little Axe Indep. Sch. Dist. No. 70, 766 F.2d 1391, 1397 (10th Cir. 1985))

478. See Abby Goodnough, Student Faces Town's Wrath in Protest Against Prayer, N.Y. Times, Jan. 27, 2012, at A11-A12. I thank Professor Enrique Guerra Pujol for alerting me to this case. 
newspaper reported that State Representative Peter G. Palumbo attacked a teenage girl who challenged a school prayer poster, denouncing her on a popular radio station as "an evil little thing." threats she received, the teenager was only able to attend school under police escort. ${ }^{480}$ In yet another school prayer case, a child had to be relocated to another school. ${ }^{481}$

Thus, political divisiveness, whether the result of religion in the schools or in the parks, is a genuine concern both to the safety of religious nonadherents and of the government. As the Lemon Court reminds us:

We have an expanding array of vexing issues, local and national, domestic and international, to debate and divide on. It conflicts with our whole history and tradition to permit questions of the Religion Clauses to assume such importance in our legislatures and in our elections that they could divert attention from the myriad issues and problems that confront every level of government. ${ }^{42}$

This is not to insinuate that voter apathy is ideal. Some fear that allowing judges to invalidate laws on the basis of political divisiveness would hamper voter participation in the political process. ${ }^{483}$ The value of the political divisiveness test, however, is its protection of religious minorities and the political process by serving as a " 'warning signal' of other pitfalls under the 'purpose' or 'effect' standards." 484 "The very purpose of a Bill of Rights was to withdraw certain subjects from vicissitudes of political controversy, to place them beyond the reach of majorities and officials.... [Such] fundamental rights may not be submitted to vote; they depend on the outcomes of no elections." Thus, whether manifested by political divisiveness or ongoing government surveillance of compliance with reversionary clauses or

\footnotetext{
479. See id. at A11.

480. See id.

481. Laura S. Underkuffler, Through a Glass Darkly: Van Orden, McCreary, and the Dangers of Transparency in Establishment Clause Jurisprudence, 5 FIRST AMEND. L. REV. 59, 79 (2006) (citing Neela Banerjee, Famillies Challenging Religious Influence in Delaware Schools, N.Y. TIMES, Jul. 29, 2006, at A10).

482. Lemon v. Kurtzman, 403 U.S. 602, 623 (1971).

483. See Gaffney, supra note 451, at 232.

484. Ripple, supra note 409, at 1203 (quoting Comm. for Pub. Educ. v. Nyquist, 413 U.S. 756, 798 (1973); Lemon, 403 U.S. at 624-25)).

485. W. Va. State Bd. of Educ. v. Barnette, 319 U.S. 624, 638 (1943).
} 
restrictive covenants, government privatization of public land implicates government entanglement with religion.

\section{VII.CONCLUSION}

The Establishment Clause should not be nullified by "evasive schemes ... whether attempted 'ingeniously or ingenuously." "486 Land sales and transfers and exercise of eminent domain are ingenious ploys governments use to avoid removing religious symbols from public land. A review of the government's purported secular purposes reveals that they are a sham for preserving the government's religious message. Governmental bodies have justified land dispositions as a basis for preserving a memorial or commemoration of secular events and ideals. But these religious objects hold no unique connection to the events they are intended to memorialize, and in fact may risk perpetuating sectarian preferences. Governments can provide memorials and comply with the Establishment Clause without the infusion of religion. Additionally, concerns that removal of the religious object would show disrespect to religion fails to account for the disrespect religious adherents feel over the secularization of their revered symbols. Even if all religious adherents would be offended by the object's removal, "it does not follow that the government can decline to cure an Establishment Clause violation in order to avoid offense." ${ }^{487}$ Therefore, governments lack a predominantly secular interest in privatizing religious symbols and the underlying land, which alone is enough to invalidate such actions under the Lemon and endorsement tests.

Also, a reasonable observer would view privatization of public land in lieu of removing the religious object as government endorsement of religion. Herculean efforts ${ }^{488}$ exerted by the government, and the history of religious activities that have occurred at the religious symbol's site contribute to the perception of government endorsement, which fencing and disclaimers cannot mitigate. Restrictive covenants that require maintenance of the symbol and reversionary clauses that entangle the government in religion further magnify the perception of government endorsement. Finally, coupled with the government speech doctrine,

\footnotetext{
486. Cooper v. Aaron, 358 U.S. 1, 17 (1958) (quoting Smith v. Texas, 311 U.S. 128, 132 (1940) (discussing children's right to integrated schools)).

487. Salazar v. Buono, 130 S. Ct. 1803, 1839 n.11 (2010) (Stevens, J., dissenting).

488. Buono III, 364 F. Supp. 2d 1175, 1182 (C.D. Cal. 2005), aff'd sub nom. Buono IV, 527 F.3d 758 (9th Cir. 2008), rev'd and remanded sub nom. Salazar v. Buono, 130 S. Ct. 1803 (2010).
} 
privatization of religious symbols and their surrounding land would enable the government to circumvent the Free Speech and Establishment Clauses.

Thus, the best course of action that comports with the Constitution is obvious - remove the religious symbol from public land. Removing the religious symbol gives the greatest effect to the Establishment Clause by accommodating the interests of the public, religious adherents, and nonbelievers. The public land can and should be preserved for public use instead of being carved up through privatization. Religious adherents need not suffer the dilution of their sacred religious symbols through government secularization, and nonbelievers may participate as full members of society without the exclusionary message sent by land dispositions. 